Type of the Paper (Article)

\title{
Effects of Methanolic Leaf Extract of Clinacanthus nutans on Fatty Acid Composition and Gene Expression in Male Obese Mice.
}

\author{
Samiaa Jamil Abdulwahid1,4, Meng Yong Goh², Mahdi Ebrahimi'², Norhafizah Mohtarrudin ${ }^{3}$, Zailina Binti \\ Hashim $^{1}$ \\ ${ }^{1}$ Department of Environmental and Occupational Health, Faculty of medicine and Health Science, University \\ Putra Malaysia, 43400, Serdang, Selangor, Malaysia. ${ }^{2}$ Department of Veterinary Preclinical Sciences, Faculty \\ of Veterinary Medicine, Universiti Putra Malaysia, 43400 UPM, Serdang, Selangor, Malaysia. ${ }^{3}$ Pathology \\ Department, Faculty of Medicine and Health Sciences, University Putra Malaysia, 43400 UPM Serdang \\ Selangor. " Department of General Science, Faculty of Education, Soran Universiti, Kurdistan Region of Iraq, \\ Iraq.
}

15amiaa.abdulwahid@gmail.com. ²mehdiebrahimii@gmail.com.

2gohyongmeng@gmail.com

3norhafizahm@upm.edu.my

1zailina@upm.edu.my

\begin{abstract}
Obesity is a universal health concern that can lead to serious diseases. The side effects of synthetic anti-obesity drugs necessitate the finding of suitable natural/herbal alternatives. Mother nature offers a wide range of plants with medicinal properties that include crude extracts and isolated compounds which are effective for controlling and reducing weight gain. Obesity was induced in 60, 3-week-old male ICR mice, using high-fat diet $(60 \%$ dietary energy from fat) for 16-week. The mice were divided at random into six groups with 10 mice: mice fed with high-fat diet (HFD) only, mice fed normal diet only (NC), and orlistat at $15.9 \mathrm{mg} / \mathrm{kg}$ (HFD+Orlistat), and mice in three other high-fat diet groups treated with methanolic leaf extract of Clinacanthus nutans (MECN) at 500, 1000 and $1500 \mathrm{mg} / \mathrm{kg}$. After 21-day of the treatment, MECN significantly reduced $(\mathrm{P}<0.05)$ the body weight, visceral fat and muscle saturated fatty acid compositions. There was also significant downregulation of HSL, PPAR $\alpha$ and PPAR $\gamma$ and SCD genes expressions in the obese mice treated with $1500 \mathrm{mg} / \mathrm{kg}$ MECN compared to the HFD group. Therefore, MECN is a potentially useful natural supplement for alleviating obesity and obesity-mediated metabolic diseases.
\end{abstract}

Keywords: Obesity; plant secondary compound; Clinacanthus nutans; gene expression. 


\section{Introduction}

Obesity is a global disease associated with hereditary and environmental factors. Current estimations suggest that, by 2030, the population of overweight and obese adults worldwide will reach 2.16 billion and 1.12 billion, respectively [1]. $\mathrm{Ng}$ et al. [2] estimated that overweight and obesity result in 3.4 million deaths worldwide, as well as 3.9 years of life loss and 3.8\% of disability-adjusted life-years (DALYs). The Asia Roundtable on Food Innovation for Improved Nutrition has reported that obesity accounts for 10 to $19 \%$ of the overall healthcare costs in Malaysia, totaling RM 4.26-8.53 billion [3]. In the US, similar reports suggest that every American adult will be either overweight or obese by 2048. This will increase the expenditure attributed to obesity, costing USD $860.7-956.9$ billion or $16-18 \%$ of the overall US healthcare expenditure by 2030 [4]. If no serious actions are taken, obesity may reach the pandemic level in 2040 [5]. Obesity refers to the excessive fat accumulation in the body. The distribution of accumulating adipose tissue can be classified into lower body fat, abdominal subcutaneous (under the skin) or visceral fat, which is found in the abdominal cavity among organs [6]. The increased visceral adiposity may cause metabolic disorders, including dyslipidemia, hypertension, insulin resistance and type 2 diabetes, whereas the peripheral (subcutaneous) obesity may not [7]. It is worth noting that liver is home to lipid, protein and sugar metabolism. The liver plays the main role in maintaining the homeostatic mechanism and the coordinated lipid metabolism in the fed and fasted conditions. The dysregulation of this correspondence has far been associated with the growth of risky genes that could cause metabolic disorder, such as hyperlipidemia and non-alcoholic fatty liver disease (NAFLD). The loss of balance between fat intake and energy consumption is thought to be the underlying cause of developing obesity phenotype $[8,9]$. Conversely, cutting down the amount of food intake can lower the oxidative stress and increase maximum lifespan. Thus, the quality, quantity and composition of food intake are crucial for regulating the level of oxidative stress. In addition to the direct chemical actions, micronutrient and phytochemicals can inhibit oxidative stress by influencing the gene expression and signal transduction in non-antioxidant manners. Oxidative stress can be lowered by reducing the expression of free radical scavenging enzymes and reducing the expression that produces enzymes like Lipid peroxidation, superoxide dismutase, superoxide dismutase, glutathione peroxidase, and catalase. Similarly, it can also be lowered by influencing the lipid and glucose homeostasis, as well as reducing the systemic glucose and lipid-mediated oxidative and endoplasmic reticulum (ER) stress [10, 11]. Attempts at treatments via anti-obesity drugs are hampered by their side-effects [12]. For example, Ferraze et al. [13] studied orlistat, one of the most common anti-obesity drugs concurrently used in clinical settings. 
It inhibits the gastric and pancreatic lipases and consequently reduces the lipid absorption from the gut [14]. The side effects of sibutramine, which was associated with myocardial ischemia, have been the reason for the withdrawals of this product from the market in several countries [12]. A recent work has suggested the effectiveness of Clinacanthus nutans Lindau, a plant from the family of Acanthaceae. It is commonly known as Sabah snake grass in Malaysia, but also has other vernacular names: Belalai Gajah (Malay), Dandang gendis (Javanese), Tajam (Sunda) in Indonesia; Phaya Yo, Phaya Plong Thong in Thailand; Twist of Flowers, Alligator Flower, Zuihua in Chinese. It is intensively grown in tropical and subtropical Asian countries including Malaysia, Indonesia, Thailand, China and Vietnam [15]. Clinacanthus nutans contains important constituents such as phenolics, flavonoids, stigmasterol, $\beta$-sitosterol, lupeol, betulin, chlorophyll derivatives, protocatechuic acid, C-glycosyl flavones, vitexin, isovitexin, shaftoside, isomollupentin, 7-O- $\beta$-glucopyranoside, orientin, isoorientin, cerebrosides, steroids, triterpenoids, glycerides, monoacylmonogalactosylglycerol and sulfur-containing glucosides [16-18]. The phytochemical compounds, namely phenols, tannins, alkaloids, steroids, protocatechuic acid, and terpenes, may have the ability to exert hypolipidemic activity [19]. Different plant-based polyphenols have been found to quench free radicals and exhibit anti-inflammatory properties, as well as anti-hyperglycemic and anti-hyperlipidemic properties [20, 21]. However, there is no evidence demonstrating that Clinacanthus nutans can be utilized as a remedy for obesity. Despite all known biological activities in earlier work, empirical evidence that supports its ability to reduce weight and lower blood cholesterol has not been reported. The present study aims to investigate this plant by using doses of methanolic leaf extract of Clinacanthus nutans (MECN) similar to previous research $[22,24]$. Recent evidence has shown that methanolic leaf extract of Clinacanthus nutans improves lipid profiles in rats [17]. Polyphenols have been known to regulate lipid metabolism by inducing metabolic gene expression or trigger the transcription factors that play a significant part in metabolizing energy [25]. There are numerous mechanisms for the reduction of adipogenesis, such as suppression of growth and differentiation of adipocytes by inhibiting the PPAR $\gamma$ and SREBP2 gene expression [26]. Besides, the downregulation of SCD gene can stimulate the insulin sensitivity action, and thus produce effective energy utilization [27]. The present study aims to examine the effect of methanolic leaf extract of Clinacanthus nutans on the mRNA expression levels of the different genes. However, even though the presence of polyphenols in C. nutans has been determined, there is still little evidence about the anti-obesity properties and the mechanism by which C. nutans could exert anti- obesity effects. To date, empirical evidence about the effect of methanolic leaf extract of Clinacanthus nutans on high-fat-diet-induced obese mice is still largely lacking. 
Therefore, this current research has investigated the effect of methanolic leaf extract of Clinacanthus nutans supplementation on $t$ on body weight parameters, fatty acid composition and the different genes involved in the regulation of lipid metabolism in obese mice fed HFD.

\section{Results}

\subsection{Body Weight Changes}

Feeding mice with high fat-diet (HFD) over a period of 16 weeks increased the body weight of experimental group mice. The mice were accordingly treated with $\mathrm{MECN}$ for 21 days and examined for changes in the body weight and biochemical parameters. There was a significant correlation between the metabolism of mice and MECN treatment; MECN has the ability to reduce weight gain in mice obesity. Table 1 demonstrates the effect of MECN on the body weight of obese mice, where the body weight of mice was in the range of $38.88 \mathrm{~g}$ to $39.22 \mathrm{~g}$. No notable differences were observed between the body weights of HFDC mice, NC mice, HFD+Orlistat, HFD+CN500, HFD+CN1000 mice, and HFD+CN1500 mice before starting the treatment. On the other hand, on completion of the supplementation program, there was a considerably higher body weight gain for the HFDC mice group compared to the group treated with MECN. Furthermore, loss of body weight in mice on MECN treatment was computed by subtracting the initial body weight from the final body weight. The final body weight in week 3 showed a significantly $(\mathrm{P}<0.05)$ lower weight measurement in high-fat diet group treated with MECN 1000 mg/kg (HFD+CN 1000) and MECN 1500 mg/kg (HFD+CN1500) compared to the HFDC group. Besides, the body weight of HFD+Orlistat group, compared to HFDC group, has significantly decreased after 3 weeks of orlistat administration, but the body weight of the high-fat diet group treated with MECN $500 \mathrm{mg} / \mathrm{kg}$ (HFD+CN500) did not significantly differ from that of the NC and HFDC groups. The results demonstrated that there was a considerable difference between the body weight of high-fat diet mice HFDC group and mice treated with 1000 and $1500 \mathrm{mg} / \mathrm{kg}$ of MECN after 21 days of administration. 
Table 1. Effect of methanolic leaf $C$. nutans on body weight in obese mice.

\begin{tabular}{lllll}
\hline Treatment & $\begin{array}{l}\text { Initial body } \\
\text { weight }(\mathrm{g})\end{array}$ & $\begin{array}{l}\text { Final body } \\
\text { weight } \\
(\mathrm{g})\end{array}$ & $\begin{array}{l}\text { Body weight loss }(\mathrm{g})= \\
\text { Initial body weight-final } \\
\text { body weight }\end{array}$ & $\begin{array}{l}\text { Weight decrease } \\
(\%)\end{array}$ \\
\hline HFDC & $39.22 \pm 1.41^{\mathrm{a}}$ & $39.14 \pm 1.56^{\mathrm{a}}$ & $0.08 \pm 1.70^{\mathrm{a}}$ & $0.20 \%$ \\
NC & $39.12 \pm 1.66^{\mathrm{a}}$ & $38.5 \pm 1.91^{\mathrm{a}}$ & $0.62+1.50^{\mathrm{a}}$ & $1.58 \%$ \\
HFD+Orlistat & $38.88 \pm 0.75^{\mathrm{a}}$ & $32.77 \pm 1.17^{\mathrm{b}}$ & $6.11 \pm 0.75^{\mathrm{b}}$ & $15.71 \%$ \\
HFD+CN500 & $39.10 \pm 1.02^{\mathrm{a}}$ & $36.62 \pm 1.88^{\mathrm{ab}}$ & $2.48 \pm 0.97^{\mathrm{ab}}$ & $6.34 \%$ \\
HFD+CN1000 & $39.20 \pm 2.00^{\mathrm{a}}$ & $33.40 \pm 1.85^{\mathrm{b}}$ & $5.8 \pm 2.0^{\mathrm{b}}$ & $14.79 \%$ \\
HFD+CN1500 & $39.20 \pm 1.00^{\mathrm{a}}$ & $33.12 \pm 1.38^{\mathrm{b}}$ & $6.08 \pm 1.05^{\mathrm{b}}$ & $15.51 \%$ \\
\hline
\end{tabular}

HFDC: high-fat diet control mice, NC: normal control mice, HFD+Orlistat: high-fat diet mice treated with orlistat, HFD+CN500: high-fat diet mice treated with C. nutans $500 \mathrm{mg} / \mathrm{kg}$, HFD+CN1000: high-fat diet mice treated with C. nutans $1000 \mathrm{mg} / \mathrm{kg}$, HFD+CN1500: high-fat diet mice treated with C. nutans $1500 \mathrm{mg} / \mathrm{kg}$. Values were expressed as mean \pm SEM $(n=10)$. Means within a row with different letters denote significant difference $(P<0.05)$.

\subsection{Visceral Fat and Organs' Weight}

There was a significant correlation between the accumulation of visceral fat and a high-fat diet, which ordinarily causes obesity. There was also a similar relationship between the fat index and the adverse effect of metabolic syndrome. Feeding the animal with high-fat diet over 16 weeks has increased the visceral fat. Table 2 provides information about the visceral fat and the weight of organs (carcass, liver, kidney, spleen and intestine). The visceral fat was collected during the post-mortem of the mice. The results indicated that the weight of visceral fat of HFD+CN1500 group was significantly $(\mathrm{p}<0.05)$ lower than that in the HFDC group, which suggests that the treatment with MECN extract has a significant effect on visceral fat. After the treatment, the two groups, particularly the high-fat diet group treated with MECN at $500 \mathrm{mg} / \mathrm{kg}$ (HFD+CN500) and that one treated with $1000 \mathrm{mg} / \mathrm{kg}(\mathrm{HFD}+\mathrm{CN} 1000)$ and with (HFD+Orlistate), showed an insignificant reduction in fat accumulation. The weight of the organs, including carcass, liver, kidney, spleen and intestine was also reduced by MECN treatment, but not significantly. 
Table 2. Organ weight of obese mice in the different treatment groups

\begin{tabular}{lllllll}
\hline Organ weight & HFD & ND & HFD+Orlistat & HFD+CN500 & HFD+CN1000 & HFD+CN1500 \\
\hline Visceral fat & $1.40 \pm 0.18^{\mathrm{a}}$ & $1.31 \pm 0.21^{\mathrm{a}}$ & $0.82 \pm 0.21^{\mathrm{ab}}$ & $0.88 \pm 0.18^{\mathrm{ab}}$ & $1.22 \pm 0.18^{\mathrm{ab}}$ & $0.69 \pm 0.1^{\mathrm{b}}$ \\
Carcass & $18.52 \pm 0.84^{\mathrm{ab}}$ & $19.26 \pm 0.97^{\mathrm{a}}$ & $15.88 \pm 0.97^{\circ}$ & $17.79 \pm 0.84^{\mathrm{ab}}$ & $16.34 \pm 0.84^{\mathrm{b}}$ & $16.17 \pm 0.75^{\circ}$ \\
Liver ${ }^{\text {ns }}$ & $2.00 \pm 0.15$ & $1.69 \pm 0.18$ & $1.99 \pm 0.18$ & $1.71 \pm 0.15$ & $1.64 \pm 0.15$ & $1.55 \pm 0.14$ \\
Kidney & $0.65 \pm 0.04^{\mathrm{a}}$ & $0.54 \pm 0.04^{\mathrm{ab}}$ & $0.57 \pm 0.04^{\mathrm{ab}}$ & $0.56 \pm 0.04^{\mathrm{ab}}$ & $0.52 \pm 0.04^{\mathrm{ab}}$ & $0.52 \pm 0.03^{\mathrm{ab}}$ \\
Spleen ${ }^{\text {ns }}$ & $0.16 \pm 0.13$ & $0.57 \pm 0.15$ & $0.25 \pm 0.15$ & $0.14 \pm 0.13$ & $0.14 \pm 0.13$ & $0.15 \pm 0.11$ \\
Intestine & $3.18 \pm 0.23^{\mathrm{ab}}$ & $3.52 \pm 0.29^{\mathrm{a}}$ & $2.58 \pm 0.27^{\mathrm{b}}$ & $3.04 \pm 0.23^{\mathrm{ab}}$ & $3.09 \pm 0.23^{\mathrm{ab}}$ & $3.07 \pm 0.21^{\mathrm{ab}}$ \\
\hline
\end{tabular}

HFDC: high-fat diet control mice, NC: normal control mice, HFD+Orlistat: high-fat diet mice treated with orlistat, HFD+CN500: high-fat diet mice treated with C. nutans $500 \mathrm{mg} / \mathrm{kg}$, HFD+CN1000: high-fat diet mice treated with C. nutans $1000 \mathrm{mg} / \mathrm{kg}$, HFD+CN1500: high-fat diet mice treated with C. nutans $1500 \mathrm{mg} / \mathrm{kg}$. Values were expressed as mean \pm SEM $(n=10)$. Means within a row with different letters are significance difference $(\mathrm{P}<0.05)$. 


\subsection{Muscle Cholesterol Levels}

Cholesterol concentration was determined by using a cholesterol standard (Sigma L-4646). As shown in Figure 1, no significant reduction was detected in HFD+CN500 (treated with $500 \mathrm{mg} / \mathrm{kg}$ of MECN; $0.26 \pm 0.03 \mu \mathrm{g})$ HFD+CN1000 $(1000 \mathrm{mg} / \mathrm{kg} ; 0.27 \pm 0.03 \mu \mathrm{g})$ and HFD+CN1500 (1500 $\mathrm{mg} / \mathrm{kg} ; 0.22 \pm 0.03 \mu \mathrm{g})$ groups, compared to the HFDC $(0.29 \pm 0.03 \mu \mathrm{g})$ group.

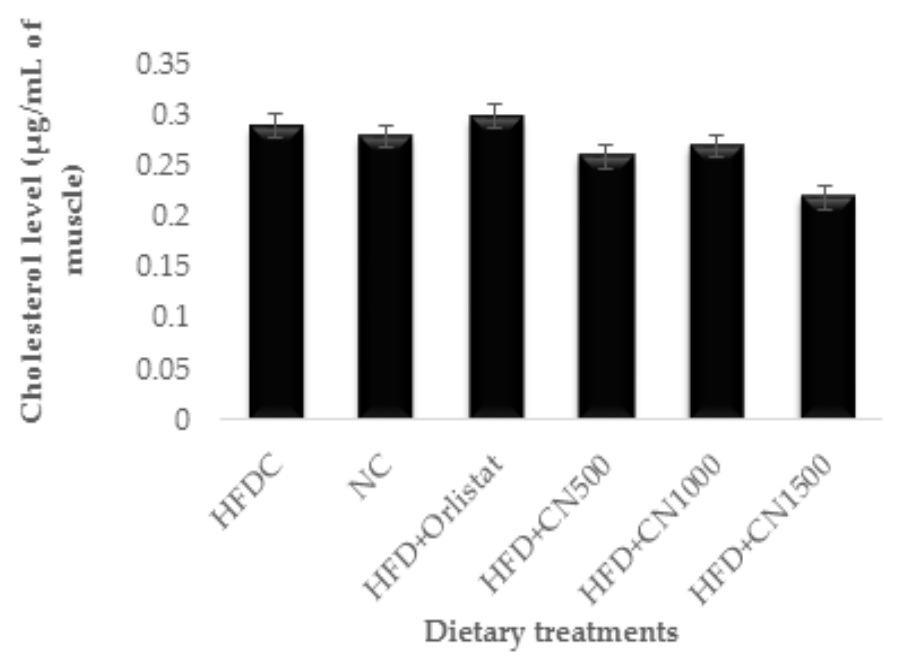

Figure 1. Effects of methanolic leaf extract of $C$. nutans on cholesterol levels in muscle of mice in comparison with the vehicle control group. HFDC: high-fat diet control mice, NC: normal control mice, HFD+Orlistat: high-fat diet mice treated with orlistat, HFD+CN500: high-fat diet mice treated with C. nutans $500 \mathrm{mg} / \mathrm{kg}$, HFD+CN1000: high-fat diet mice treated with C. nutans 1000 mg $/ \mathrm{kg}$, HFD+CN1500: high-fat diet mice treated with $C$. nutans $1500 \mathrm{mg} / \mathrm{kg}$. Values are expressed as mean \pm SEM ( $\mathrm{n}=10)$. Different lowercase letters denote significant difference $(\mathrm{P}<0.05)$. 


\subsection{Muscle Malondialdehyde Levels}

The value of malondialdehyde (MDA) in this experiment was determined using triethyl phosphate (TEP) standard. As presented in Figure 2, there is no significant reduction in the high-fat diet group treated with MECN extract at $500 \mathrm{mg} / \mathrm{kg}(10.71 \pm 2.15 \mathrm{mg} \mathrm{MDA} / \mathrm{kg}$ mice), $1000 \mathrm{mg} / \mathrm{kg}(11.08 \pm 2.15$ $\mathrm{mg} \mathrm{MDA} / \mathrm{kg}$ mice), $1500 \mathrm{mg} / \mathrm{kg}(10.01 \pm 1.8 \mathrm{mg} \mathrm{MDA} / \mathrm{kg}$ mice) compared to the HFDC $(13.33 \pm 2.15$ $\mathrm{mg} \mathrm{MDA} / \mathrm{kg}$ mice) group. No significant differences $(\mathrm{p}<0.05)$ were noted in the muscle MDA level in all groups of MECN compared to control group.

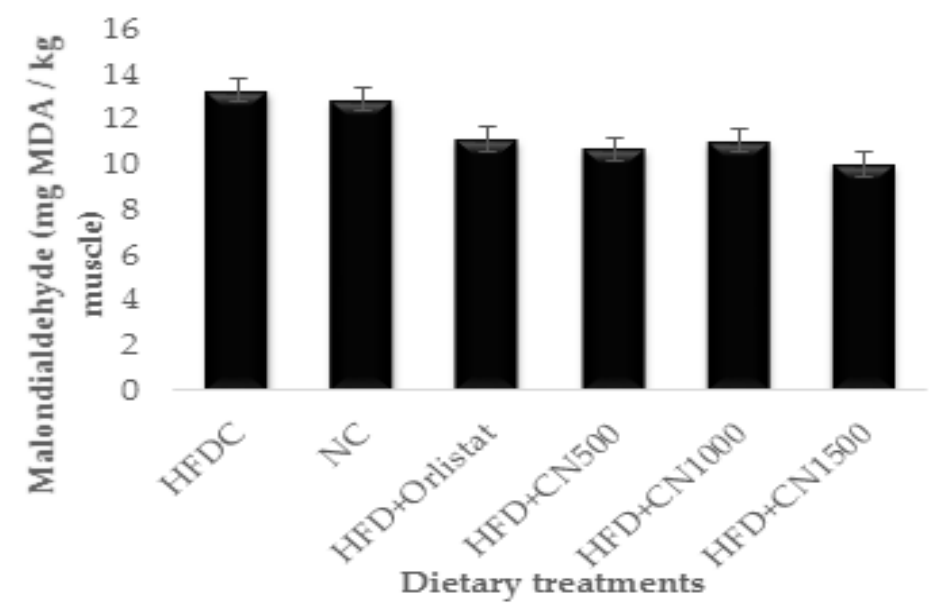

Figure 2. Effects of methanolic leaf extract of $C$. nutans on the level of malondialdehyde (MDA) in muscle of mice comparison with the vehicle control group. HFDC: high-fat diet control mice, NC: normal control mice, HFD+Orlistat: high-fat diet mice treated with orlistat, HFD+CN500: high-fat diet mice treated with C. nutans 500 mg/kg, HFD+CN1000: high-fat diet mice treated with C. nutans 1000 mg/kg, HFD+ CN1500: high-fat diet mice treated with $C$. nutans $1500 \mathrm{mg} / \mathrm{kg}$. Values are expressed as mean \pm SEM ( $\mathrm{n}=10)$. Different lowercase letters denote significant difference $(\mathrm{P}<0.05)$. 


\subsection{Muscle Fatty Acid Compositions}

The fatty acid composition of the muscle from control groups HFDC, NC and mice treated with the methanolic extract of C. nutans leaf is shown in Table 3. The major fatty acids found in the HFDC group consist of the saturated fatty acids, which are palmitic acids (C16:0) at 22.17\%. This result was significantly higher than the group with high-fat diet treated with MCEN, HFD+CN500 (15.65\%), HFD+CN1000 (16.58\%) and HFD+CN1500 (15.57\%). On the other hand, the oleic acid (C18:1n-9), which is one of the unsaturated fatty acids, was significantly lower in the HFDC group at (41.14\%), compared to the high-fat diet treated MECN, HFD+CN500 (53.88\%), HFD+CN1000 (54.17\%) and HFD+CN1500 (54.87\%). However, HFDC group showed a significant increase in total saturated fatty acid $(28.86 \%)$ and a decrease in monounsaturated fatty acid $47.48 \%$ compared to high-fat diet treated MECN. 
Table 3. Effects of methanolic extract of $C$. nutans leaf on fatty acids composition in muscle mice as compared with the vehicle control group.

\begin{tabular}{|c|c|c|c|c|c|c|c|}
\hline $\begin{array}{c}\text { Fatty acid } \\
\text { profile }\end{array}$ & & HFDC (\%) & NC (\%) & $\begin{array}{c}\text { HFD+Orlistat } \\
(\%)\end{array}$ & $\begin{array}{c}\text { HFD+CN500 } \\
(\%)\end{array}$ & $\begin{array}{c}\text { HFD+CN1000 } \\
(\%)\end{array}$ & $\begin{array}{l}\text { HFD+CN1500 } \\
(\%)\end{array}$ \\
\hline $\mathrm{C} 14: 0^{\mathrm{ns}}$ & Myristic & $1.42 \pm 0.19$ & $1.75 \pm 0.21$ & $1.29 \pm 0.19$ & $1.17 \pm 0.19$ & $1.24 \pm 0.21$ & $1.38 \pm 0.19$ \\
\hline C16:0 & Palmitic & $22.17 \pm 0.74^{\mathrm{a}}$ & $15.77 \pm 0.81^{\mathrm{b}}$ & $17.49 \pm 0.74^{b}$ & $15.65 \pm 0.74^{\mathrm{b}}$ & $16.58 \pm 0.81^{b}$ & $15.57 \pm 0.74^{b}$ \\
\hline $\mathrm{C} 16: 1^{\mathrm{ns}}$ & Palmitoleic & $6.33 \pm 0.84$ & $5.96 \pm 0.92$ & $4.61 \pm 0.84$ & $5.23 \pm 0.84$ & $5.40 \pm 0.92$ & $4.95 \pm 0.84$ \\
\hline $\mathrm{C} 18: 0^{\mathrm{ns}}$ & Stearic & $5.26 \pm 1.20$ & $5.98 \pm 1.31$ & $8.68 \pm 1.20$ & $6.59 \pm 1.20$ & $6.64+1.31$ & $6.38 \pm 1.20$ \\
\hline C18:1n-9 & Oleic & $41.14+2.31 c$ & $55.82+2.53^{a}$ & $47.45 \pm 2.31^{\mathrm{bc}}$ & $53.88 \pm 2.31$ ab & $54.17 \pm 2.53$ ab & $54.87 \pm 2.31$ ab \\
\hline$C 18: 2 n-6$ & Linoleic & $15.72 \pm 0.71^{\text {a }}$ & $9.29 \pm 0.77^{\circ}$ & $9.76 \pm 0.71^{b}$ & $10.68 \pm 0.71^{\mathrm{b}}$ & $9.29 \pm 0.77^{\circ}$ & $10.27 \pm 0.71^{b}$ \\
\hline$C 18: 3 n-3^{n s}$ & Linolenic & $1.54 \pm 0.16$ & $1.25 \pm 0.18$ & $1.11 \pm 0.16$ & $1.12+0.16$ & $1.30 \pm 0.18$ & $1.31 \pm 0.16$ \\
\hline$C 20: 4 n-6^{n s}$ & Arachidonic & $2.98 \pm 0.74$ & $1.73 \pm 0.81$ & $4.08 \pm 0.74$ & $2.78 \pm 0.74$ & $2.61 \pm 0.81$ & $2.55 \pm 0.74$ \\
\hline$C 20: 5 n-3$ & Eicosapentaenoic & $0.21 \pm 0.06^{b}$ & $0.19 \pm 0.07 \mathrm{~b}$ & $0.49 \pm 0.06^{\mathrm{a}}$ & $0.23 \pm 0.06^{b}$ & $0.22+0.07 \mathrm{~b}$ & $0.26 \pm 0.06^{b}$ \\
\hline$C 22: 5 n-3^{n s}$ & Docosapentaenoic & $0.89 \pm 0.21$ & $0.47 \pm 0.23$ & $1.08 \pm 0.21$ & $0.44+0.21$ & $0.61 \pm 0.23$ & $0.48 \pm 0.21$ \\
\hline$C 22: 6 n-3$ & Docosahexaenoic & $2.29 \pm 0.64^{\mathrm{ab}}$ & $1.72+0.70^{b}$ & $3.90 \pm 0.64^{\mathrm{a}}$ & $2.19 \pm 0.64 \mathrm{ab}$ & $1.91 \pm 0.70^{\mathrm{ab}}$ & $1.93 \pm 0.64^{\mathrm{ab}}$ \\
\hline Total SFA & Total saturated FA & $28.86 \pm 1.19^{a}$ & $23.52+1.30^{c}$ & $27.47 \pm 1.19^{\mathrm{ab}}$ & $23.42+1.19 c$ & $24.46 \pm 1.30^{\mathrm{bc}}$ & $23.33 \pm 1.19 c$ \\
\hline Total MUFA & Monounsaturated FA & $47.48+2.80 c$ & $61.8 \pm 3.06^{\mathrm{a}}$ & $52.06 \pm 2.80 \mathrm{bc}$ & $59.11+2.80$ ab & $59.58 \pm 3.06^{\mathrm{ab}}$ & $59.83 \pm 2.80 \mathrm{ab}$ \\
\hline PUFAn-6 & Polyunsaturated FA & $18.70 \pm 1.12^{a}$ & $11.02+1.23^{b}$ & $13.86 \pm 1.12^{\circ}$ & $13.47 \pm 1.12^{\circ}$ & $11.90 \pm 1.23^{b}$ & $12.83 \pm 1.12^{\mathrm{b}}$ \\
\hline PUFA n-3ns & Polyunsaturated FA & $4.95 \pm 0.95$ & $3.65 \pm 1.04$ & $6.6 \pm 0.95$ & $3.99 \pm 0.95$ & $4.05 \pm 1.04$ & $3.99 \pm 0.95$ \\
\hline FAR n-6:n-3 & Fatty acid ratio & $4.20 \pm 0.40^{\mathrm{a}}$ & $3.29 \pm 0.44^{\mathrm{ab}}$ & $2.22+0.40^{\mathrm{b}}$ & $4.38 \pm 0.40^{\mathrm{a}}$ & $3.04 \pm 0.44^{\mathrm{ab}}$ & $3.48 \pm 0.40^{\mathrm{ab}}$ \\
\hline
\end{tabular}

HFDC: high-fat diet control mice, NC: normal control mice, HFD+Orlistat: high-fat diet mice treated with orlistat, HFD+CN500: high-fat diet mice treated with C. nutans $500 \mathrm{mg} / \mathrm{kg}$, HFD+CN1000: high-fat diet mice treated with C. nutans $1000 \mathrm{mg} / \mathrm{kg}$, HFD+CN1500: high-fat diet mice treated with C. nutans 1500 $\mathrm{mg} / \mathrm{kg}$. Values are expressed as mean $\pm \mathrm{SEM}(\mathrm{n}=10)$. Mean within a row with different letters are significance difference $(\mathrm{P}<0.05)$.Note: TSFA $=\mathrm{C} 14: 0+\mathrm{C} 16: 0$ $+C 18: 0)$, TMUFA $=C 16: 1+C 18: 1 n-9), n-3$ PUFA = C18:3n-3+C20:5n-3+C22:5n-3+C22:6n-3), n-6 PUFA = C18:2n-6+C20:4n-6). TPUFA=n-3 PUFA+ n-6 PUFA. $n-6: n-3$ FAR $=C 18: 2 n-6+C 20: 4 n-6 \div C 18: 3 n-3+C 20: 5 n-3+C 22: 5 n-3+C 22: 6 n-3)$. 


\subsection{Liver PPAR $\alpha$, PPAR $\gamma$, HSL, SREBP2 and SCD Gene Expression}

Using qRT-PCR, the messenger ribonucleic acid (mRNAs) expression level of genes were examined from the liver tissue of mice. This includes genes that are involved in fatty acid oxidation such as PPAR $\alpha$ and HSL, as well as those involved in fatty acid synthesis and adipogenesis such as PPAR $\gamma$, SREBP and SCD genes involved were analyzed in liver tissue of mice by qRT-PCR. In this study, the expression profile of five genes, namely PPAR $\alpha$, PPAR $\gamma$, HSL, SREBP, and SCD, were validated, differentially expressed and reported for their upregulation or downregulation. As shown in Figure 3-A, the control group NC $(0.38 \pm 0.09)$ and the high-fat diet group treated with MECN, HFD+CN500 $(0.23 \pm 0.09), H F D+C N 1000(0.49 \pm 0.09)$ and HFD+CN1500 $(0.06 \pm 0.08)$ group significantly downregulated the activity of PPAR $\alpha$ when compared to the HFDC $(1 \pm 0.07)$ group. In fact, for PPAR $\alpha$, the expression level in HFD+CN500 was lower than HFD+CN1000, indicating that different concentrations of $C$. nutans levels affected the downregulation of the PPAR $\alpha$ gene expression. For PPAR $\gamma$ mRNA treatment group in comparison with high-fat diet control HFDC group, PPAR $\gamma$ mRNA expression decreased significantly $(\mathrm{P}<0.05)$ in HFD+CN1500 $(0.40 \pm 0.11)$ relative to HFDC $(1 \pm 0.1)$ group (Figure $3-B)$. Relative hepatic gene expression HSL in the methanolic extract leaf extract of $C$. nutans treated groups was compared to HFDC and NC groups. The expression was lowered significantly $(\mathrm{P}<0.05)$ in HFD+CN1500 $(0.24 \pm 0.21)$ group in comparison with HFDC $(1 \pm 0.18)$ and NC $(1.33 \pm 0.24)$ groups for the genes HSL (Figure 3-C). Similarly, the C. nutans treatment showed significant findings for SCD and PPAR $\alpha$. Meanwhile, SCD in the high-fat diet group treated with C. nutans, HFD+CN500 (0.55 \pm 0.10$), H F D+C N 1000(0.40$ $\pm 0.10)$ and HFD+CN1500 $(0.41 \pm 0.09)$ showed a significant $(\mathrm{P}<0.05)$ downregulated activity, in comparison with the HFDC $(1 \pm 0.08)$ for SCD gene group (Figure 3-D). In addition, the SREBP2 gene transcription in (Figure 3.E) did not show any significant difference between HFDC and high-fat diet group treated with MECN. However, the SREBP2 and SCD level of gene expression in the HFD+CN1000 group was decreased more than HFD+CN1500 group.. 

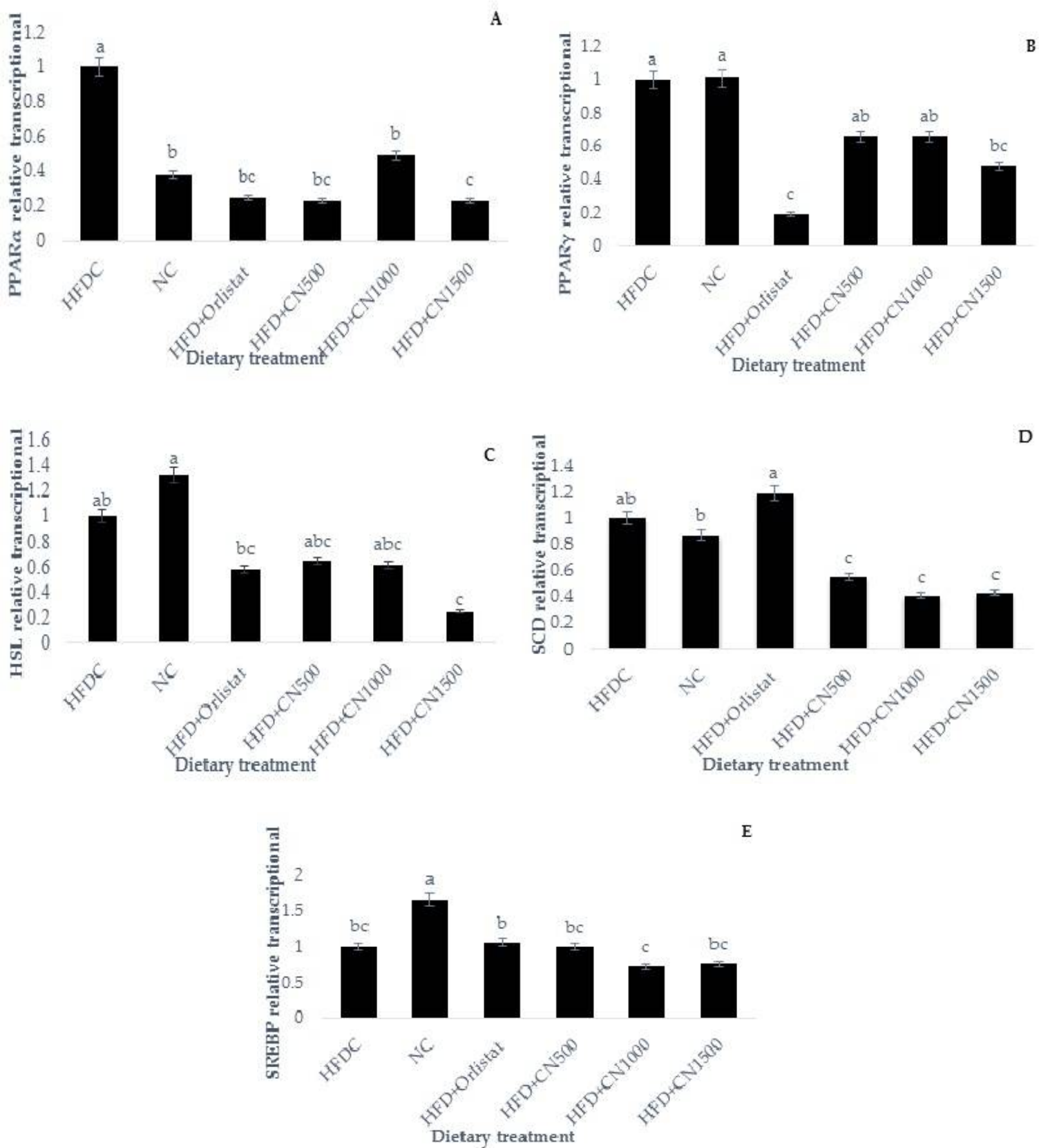

Figure 3 (A- E) Comparison of PPAR $\alpha$, PPAR $\gamma$, HSL, SREBP and SCD relative gene transcription in the mice liver tissue ( $n=6)$. HFDC: high-fat diet control mice, NC: normal control mice, HFD+Orlistat: high-fat diet mice treated with orlistat, HFD+CN500: high-fat diet mice treated with C. nutans $500 \mathrm{mg} / \mathrm{kg}$, HFD+CN1000: high-fat diet mice treated with C. nutans $1000 \mathrm{mg} / \mathrm{kg}$, HFD+CN1500: high-fat diet mice treated with C. nutans 1500 $\mathrm{mg} / \mathrm{kg}$. Values were normalized to a housekeeping gene, $\beta$-actin. Then treated samples are expressed relative to gene transcription of HFDC group. Values are expressed as mean \pm SEM. Different lowercase letters denote significant difference $(\mathrm{P}<0.05)$. 


\section{Discussion}

Obesity is presented in a large number of people who are lead a sedentary life, which is a lifestyle that is occupied by reduced activity and high-calorie intake [28]. Enlarged fat mass and increased lipid concentration in blood are often common changes seen in obese individuals [29]. According to Nishikawa et al. [30] obese animal models have varying features of obesity, and thus one should take care to choose a model that is appropriate for the specific in these factors. The data presented in this study may establish a baseline to develop animal models of high fat diet-induced obesity. Recent research typically priorities work to finding effective alternatives treatments to synthetic obesity drug management. In this respect, this study has investigated the methanolic leaf extract of C. nutans and the results showed, as discussed below, that the purpose of the experiment. The features of obesity shown by HFD feeding are affected by the sex, strain, and age of mice. Sex steroid hormone, hepatic lipid metabolism, and systemic metabolism could be implicated extract the extract has demonstrated an important role in treating obesity.

The obese rats induced by high-fat diet are preferred in obesity research as they mimic the usual features of obesity in humans. The high-fat diet is among the leading factors of obesity, where the long-term consumption of high-fat diet showed significant increases in abdominal fat weight in mammals [31]. Earlier work has shown that a high-fat diet may elevate energy intake, and thus develop obesity [1, 32]. High-fat diets usually have 32 to $60 \%$ of calories from fat. From the nutritional perspective, a human diet of $60 \mathrm{kcal} \%$ fat would be deemed to be extreme, but these are normally used to accelerate obesity in rodents and save experimental time [32]. This study has induced obesity in male ICR mice using high-fat diet for 16 weeks (60\% dietary energy from fat). At the end of the treatment, the cell size in the HFDC group showed a significant increase in comparison with MECN groups. In the current study, obesity is achieved after feeding the mice with their respective diets for 16 weeks. Using lard, Zhou et al. [33] induced obesity in male Sprague-Dawley rats by feeding them with a high-fat diet (46\% calories) for 14 weeks. Mashmoul et al. [34] suggested that inducing obesity in male rats using beef tallow would require 12 weeks of time. Administering male mice with $20 \mathrm{mg}$ of orlistat and feeding them with HFD has only reduced $0.5 \%$ of the body weight after eight weeks of treatment [34]. These reports suggest that taking orlistat and consuming HFD may result in weight loss compared to those that continue consuming a high-fat diet. In the current study, administration of $15.9 \mathrm{mg}$ of Orlistat reduced $15.71 \%$ of body weight of obese mice. According to Kumar et al. [35] orlistat and sibutramine can promote about 5 to $10 \%$ of weight loss. In this study, no difference was observed in the food intake between the HFDC group and the high-fat diet group treated with 500,1000, and $1500 \mathrm{mg} / \mathrm{kg}$ of MECN. The increase in body weight was also inhibited. The male ICR obese mice, administrated with 500, 1000 and 1500 $\mathrm{mg} / \mathrm{kg}$ respectively, had $6.34 \%, 14.79 \%$, and $15.51 \%$ of weight loss after 21 days of treatment. There were no physical challenges observed throughout the experiment.

Hayashi et al. [36] state that data for visceral fat is more important than the abdominal subcutaneous fat data for the prediction of future insulin resistance. When the visceral fat depot size is smaller, it can more effectively prevent the future elevation of the fasting plasma insulin level. In the current study, the liver and kidney weights of the high-fat diet mice on MECN treatment was slightly lower in the groups treated with HFD+CN500 and HFD+1000 compared to the obese group. According to Bailey et al. [37] analysis of organ weight through toxicology is a significant endpoint in identifying possible harmful effects of chemicals. However, these authors have suggested that variances in 
organ weight between treatment groups are frequently accompanied by differences in the body weight between groups. Clinacanthus nutans has antioxidant action represented by its polyphenols [38]. In chloroplast, thylakoids possess a hundred different membrane proteins, galactolipids and sulpholipids, in addition to different vitamins ( $\mathrm{A}, \mathrm{E}$ and $\mathrm{K}$ ), and hence a range of bioactive compounds that could cause the retardation of fat digestion [39]. Sprague Dawley rats had body weight loss when fed with polyphenols, such as epicatechin (EC), epigallocatechin (EGC) and epicatechin gallate (ECG) [20]. In addition, supplementing with chlorogenic acid reduces the body weight gain and adipose weight in comparison with the high-fat diet group and caffeic acid group [40]. However, the supplementation of purified anthocyanins from Chinese mulberry (Morus australis Poir) has prevented the weight gain in male mice C57BL/6 fed with high-fat diet [41]. The current findings suggest that the chlorophyll $a, b$, polyphenol, chlorogenic acid and caffic acid in the C. nutans may control the lipid metabolism by affecting hepatic lipid oxidation and lipogenesis, and thus cause an increase in energy expenditure. Thus, taking supplements that are high in antioxidants, such as methanolic extract of $C$. nutans leaf would lower the risk of obesity and oxidative stress-related disorders.

Supplementation of $C$. natans showed no noticeable effect on the muscle cholesterol level in mice. However, lower muscle cholesterol level was detected compared to their controls, Cho et al. [40] reported that caffeic acid or chlorogenic acid reduced cholesterol (plasma, adipose tissue, and heart) in ICR mice fed HFD. Baba et al. [42] showed that cocoa powder inhibited the intestinal absorption of cholesterol in rats. The authors attributed their findings to the inhibition of pancreatic lipase, which promotes cholesterol excretion in faces and reduces hepatic lipid accumulation. The inability of MECN to induce a significant decrease in muscle cholesterol could be due to the short duration of the experiment. Al-Moosawi [43] posited that changes in total cholesterol could take up to three months.

It was postulated that oxidative stress might play a crucial role in the pathophysiology of hyperlipidemia [44]. Oxidative stress is essentially an imbalance between free radical production and the body's ability to counteract or detoxify their adverse effects through neutralizations by antioxidants. An unnecessarily high and prolonged elevation in reactive oxygen species (ROS) production is believed to be responsible for the pathogenesis of cancer, atherosclerosis, diabetes type 2, neurodegenerative diseases, rheumatoid arthritis, ischemia/reperfusion injury, obstructive sleep apnea, and another disease [45]. Continuous use of high-fat diet induces increased production of ROS and its intermediates, which consequently contribute to hyperlipidemia and atherosclerosis [46]. Obesity is characterized by systemic oxidative stress [47], which leads to increase in plasma and intramuscular lipid peroxidation [48, 49]. Excess body fat is directly correlated to markers of oxidative stress including thiobarbituric acid-reactive substances (TBARS), which cause the degradation of membrane lipids and lead to cell impairment and formation of various toxic products [47]. Hence, calculating these factors can offer insights into the metabolic state of ICR obese mice. In this study, high-fat diet treated MECN 500, 1000 and $1500 \mathrm{mg} / \mathrm{kg}$ slightly reduced in lipid peroxidation compared to HFDC group but not significant. Meanwhile, Sarega et al. [17] reported that multiple phenolic compounds via protocatechuic acid, ferulic acid, gallic acid, p-coumaric, chlorogenic acid, vanillic acid and caffeic acid were detected in the extracts and fractions of $C$. nutans. In line with the current observation, plant secondary metabolites, including chlorogenic acid [50], trans-resveratrol [51, 52], epicatechin [42] and dietary fiber from cocoa [53] inhibited lipid peroxidation [41]. Fernandez-Mar et al. [51] reported that no less than $70 \%$ of ingested 
trans-resveratrol was absorbed and metabolized for the formation of glucuronide and sulfate derivatives, which inhibit pathological increases in lipid peroxidation. Thus, this study indicates that the presence of polyphenols in C.nutans might be responsible for the reduced lipid peroxidation in mice. The inability of $C$. nutans to induce a significant decrease in muscle lipid peroxidation level could be due to the short duration of the experiment.

This assumption supports the current observations on the high level of fatty acid deposits in the skeletal muscle tissues of obese mice supplemented with high-fat diet HFDC [54]. The levels (g/100g total fatty acids in the form of a percentage) of saturated fatty acids, the notable rise in the levels of saturated fatty acids, namely the palmitic acid (C16:0), in the HFDC mice were also similar to findings reported by Morselli et al. [55]. The current research also found that those groups with a high-fat diet and treated with MECN 500, 1000 and $1500 \mathrm{mg} / \mathrm{kg}$ had a significantly higher amount of oleic acid than the HFDC groups. The results showed significant differences between the palmitic acid and oleic acid levels in the HFDC and MECN groups. Similar to these findings, Graf et al. [56] found that the diet has high saturated fatty acid. The saturated fatty acid (SFA) has decreased in the plasma rats after 10 weeks of anthocyanin-rich juice consumption, whereas the polyunsaturated fatty acid (PUFA) has increased. According to previous research, the fatty acid composition of the diet is reflected by the fatty acid profile of skeletal muscle of phospholipids and triacylglycerols [57]. It is important to note that the photosynthesizing plants are particularly abundantly rich in alpha-linolenic acid (ALA), which accounts for up to $55 \%$ of the fatty acids present in green vegetables [58]. Interestingly, the $C$. nutans is rich in saturated fatty acid (SFA), such as myristic acid, palmitic acid, methyl ester palmitic acid, stearic acid, methyl ester margaric acid, linoleic acid, ethyl ester linolenic acid [59]. Several positive effects of both n-3 and n-6 PUFA have been previously reported by De Caterina [58]. Their study suggested that incorporating PUFA in cell membranes may affect the membrane fluidity. PUFA has anti-inflammatory effects [60]. The present study found that the consumption of MECN in obese mice decreases saturated fatty acid and increases the level of an unsaturated fatty acid profile in muscle.

The changes in the hepatic transcriptional profiles of obese ICR mice supplemented with methanolic extract of $C$. nutans leaf were examined. The results obtained from the experiments of gene expression are consistent with the levels that found in the liver. The plant secondary metabolites are potential regulators of gene expressions. They can act as a ligand for a specific nuclear receptor that improves the transcription rate of specific genes [61]. The peroxisome proliferator-activated receptors (PPARs) are a superfamily of receptors which belong to the steroidal or thyroid hormone receptors. These receptors are triggered by endogenous or exogenous ligands which promote the target gene transcription responsible for regulating the metabolism related to lipid, sugar and protein [62,63]. It is worth noting that PPAR $\alpha$ is one of the crucial intermediates affecting the polyphenol in liver gene expression in various aspects of lipid metabolism. Specifically, PPAR $\alpha$ functions at the center of the regulation hub. It has its effects on fatty acid uptake and intracellular binding, mitochondrial and peroxisomal fatty oxidation, ketogenesis, triglyceride turnover, gluconeogenesis, and bile synthesis/secretion [64]. For this reason, PPAR $\alpha$ agonist, such as fenofibrate have been widely used for treating hyperlipidemia [64]. There is evidence that PPAR $\alpha$ activation by fibrates inhibits the induction of IL6 and the C-reactive protein and nuclear factor kappa B levels (NF-kB) [62]. On the other hand, PPAR $\gamma$ is mainly involved in regulating the glucose homeostatic in the body. It also increases adipocytes hypertrophy or preadipocytes differentiation 
by activating the genes responsible for adipogenesis [65]. Thus, the upregulated PPAR $\gamma$ gene does promote the accumulation of adipose tissue which may stimulate obesity [26]. In the current study, the PPAR $\alpha$ mRNA expression was significantly downregulated in the liver tissue of the mice group treated with MECN than HFDC group. The PPAR $\gamma$ in the liver of mice treated with MECN $(1500 \mathrm{mg} / \mathrm{kg}$ ) was significantly downregulated when compared with the HFDC group. PPAR $\alpha$ is mostly shown in the liver and partly in the cellular lipid, while PPAR $\gamma$ is shown in adipose tissue and, to some extent, in the liver [66]. The decreased expression of PPAR $\alpha$ mRNA suggested the imbalance of lipid metabolism towards lipid accumulation in the case of induced lipogenic transcription [66]. The possible mechanism involved in this action is the hepatic autophagy gene that can regulate PPARs at various levels [67]. It activates PPAR $\alpha$ target gene [68] and suppresses the levels of PPAR $\gamma$ mRNA [69] that may activate the autophagy and control the proteins/or protein degradation involved in the metabolism of a lipid [70,71]. In the same context, PPAR $\gamma$ mRNA agonists thiazolidinediones (TZDs) are taken to induce insulin sensitivity in the obese-diabetic patients, while agonists (fibrates) are taken to medicate hyperlipidemia in patients by activating PPAR $\alpha$ target genes [72]. This supports previous reports in which PPAR $\alpha$ led to increases in energy expenditure [73]. It is also similar to other findings in which the PPAR $\alpha$ mRNA expression was significantly reduced in the liver tissue of MECN group compared to the HFDC group [73, 74]. The expression of PPAR $\alpha$ and PPAR $\gamma$ mRNA usually increases and decreases depending on the dose and duration of administration [66], as well as the spatial constraints for transcription factors and ribonucleic acid (RNA) polymerases [75]. It may be the balance of action between the PPAR $\alpha$ and PPAR $\gamma$ mRNA agonistic activity in MECN that indirectly leads to the reduction of adipogenesis in adipose tissue and liver, and thus preventing obesity. From the adipogenesis-related gene expression study, we found that the methanolic extract of C. nutans leaf at $1500 \mathrm{mg} / \mathrm{kg}$ significantly downregulated HSL. There is evidence that the green and black tea have a significant role in cellular lipid accumulation by their increase in the phosphorylation of hepatic adenosine monophosphate-activated protein kinase, and liver kinase B1 (KB1). The signaling module may be involved in this process [76]. The 3T3-L1 cells, which were treated with plant secondary compound, have increased the levels of intracellular cyclic adenosine monophosphate (cAMP) that may lead to a decrease PPAR $\gamma$ and HSL mRNA level $[77,78]$. Therefore, plant secondary compounds can modify intracellular cAMP and can act on the lipid metabolism in adipocytes PPAR $\gamma$ and HSL mRNA [77, 79]. A similar effect was observed in ICR obese mice which were orally fed with ethanolic extracts of Brassica campestris spp. rapa roots. The treatment group induced the expression in white adipocytes of lipolysis-related genes HSL [80]. The supplementation of obese mice with green tea extract has led to an increase in the gene expression of HSL mRNA [81]. However, when the 3T3-L1 cells were treated with procyanidin extracts from grape and wine, the HSL mRNA levels have decreased over time with respect to their controls [77]. On the other hand, the dosage of MECN which was given at $1500 \mathrm{mg} / \mathrm{kg}$ resulted in a significant reduction of HSL and PPAR $\gamma$ in the mice liver may enhance thermogenesis, whereas the fatty acid metabolites may prevent complete differentiation of white adipose tissue (WAT). Furthermore, the reduction in transcription of PPAR $\gamma$ seems to inhibit adipocyte differentiation and influence lipolysis and lipid deposition in adipose tissue [82]. This study has established a downregulated activity of the SCD gene expression in the liver in the groups treated with MECN compared to HFDC group. It is suggested that the downregulation of the SCD activity protects mice from obesity reduced via lipid synthesis, or it may increase energy expenditure through increased insulin sensitivity [83]. The present study, together 
with other previous studies using short-term treatment with an antisense inhibitor of SCD, is thought to be sufficient for the improvement of hepatic insulin sensitivity. Evidence has also shown that insulin-resistant obese mice $(o b / o b)$ are prone to have an upregulated hepatic SCD gene expression activity $[84,85]$. Whenever the mice are fed with a high-fat diet to induce insulin resistance, the SCD1 mRNA levels are increased. Taking these findings together, inhibition of SCD mRNA gene expression in mice may prevent the development of obesity and alleviate insulin resistance [83].

SREBPs are important transcription factors that regulate fatty acid and cholesterol metabolism in the liver [86]. There was no significant difference between the high-fat diet treated with MECN groups and high-fat diet control group. Both SCD and acetyl-CoA carboxylase response to changes in physiological conditions, for example, by feeding a high carbohydrate diet, re-feeding after starvation, and administration of insulin [87]. The present study supports the finding which suggests that the regulation of SCD1 expression is not always under SREBP-1c signaling control in Zucker obese rats [88]. This suggests that the regulation of SCD1 by SREBP-1c does not always operate as effectively as has been previously believed [89]. The SREBP level did not significantly change in the liver. The difference in the level and direction of gene expression in such tissue might be due to the variation in bioavailability and metabolism of plant secondary compound polyphenols that remains unclear. Downregulated transcription factors including PPAR $\gamma$ could provide a molecular mechanism for alterations in adipocyte number and obesity [90]. In addition, the inhibition of SCD gene expression has improved insulin sensitivity, which in turn has ameliorated obesity. This study demonstrated that anti-obesity effects of HFD+CN1500 is due to the regulation of hepatic gene expression involving the downregulation of the HSL and PPAR $\gamma$ mRNA gene, with a significant reduction of the inflammatory precursors which are IL6 and leptin [91]. The study concludes that it is possible that the dosages of a MECN $1500 \mathrm{mg} / \mathrm{kg}$ may inhibit the gene expression involved in the regulation of lipid metabolism and thus may prevent obesity.

\section{Material and Methods}

\subsection{Plant Materials}

Fresh leaves of Clinacanthus nutans (Burm.f.) Lindau were acquired from a botanical garden in Ladang 10, Universiti Putra Malaysia, Selangor, Malaysia. The botanical identity of C. nutans was characterized by the Phytomedicine Herbarium, Institute of Bioscience, Universiti Putra Malaysia, Selangor (Voucher no. SK2942/15)

\subsection{Preparation of Methanolic Leaf Extract of Clinacanthus nutans}

The Clinacanthus nutans leaves were cleaned under running tap water, and then air dried for one week under direct sunlight. These leaves were oven-dried for 24 hours at $40^{\circ} \mathrm{C}$ in an oven, grounded to a fine powder by electric grinder (RT-08, Rong Tsong Precision Technology Co. Taiwan) and stored in an air-tight container. The powdered leaves were extracted using $80 \%$ methanol (by adding $20 \%$ of distilled water) at a ratio of $1: 20(\mathrm{w} / \mathrm{v}), 1 \mathrm{~g}$ of the sample to $20 \mathrm{~mL}$ of methanol. The powdered $C$. nutans leaves were left macerated in methanol and shaken for 72 hours using a rotary shaker (Liquid Brushless DC motor clock Rotary, Germany). Next, the methanol solution was 
separated from the powdered leaves by using a cloth filter, cotton wool and Whatman no. 1 filter paper (Whatman No.1, Fitchburg, WI, USA). The methanol extract was then concentrated under compact pressure with an R-215 rotating evaporator (Buchi, Flawil, Switzerland) at $40^{\circ} \mathrm{C}$. The concentrated methanol extract was stored at $-80^{\circ} \mathrm{C}$ and lyophilized with a freeze drier (Labconco Free zone 6 Plus Freeze Dryer) to dry powdered form and then kept at $-20^{\circ} \mathrm{C}$. The yield obtained from the C. nutans methanolic extract was $15.92 \%(\mathrm{w} / \mathrm{w})$.

\subsection{Animal Subjects}

All procedures conducted in this work were reviewed and approved by the Universiti Putra Malaysia Institutional Animal Care and Use Committee (IACUC) (ACUC Approval No: R083/2016). Sixty three-week-old male ICR mice $(n=60)$ were bought from Sapphire Enterprise, Malaysia. Before the trial, the subjects were acclimatized under constant conditions (temperature: $22 \pm 1^{\circ} \mathrm{C}$; humidity: $40 \%-60 \%$; light; 12 hours of light/dark cycle) for 7 days. The mice were provided with a normal purified diet consisting 10\% bovine fat D12450B (Research Diets, New Brunswick, New Jersey, USA) [92], prior to the dietary manipulation. The caloric composition of feed is $20 \mathrm{kcal} \%$ protein, $70 \mathrm{kcal} \%$ carbohydrate and $10 \mathrm{kcal} \%$ fat. Each gram of the ingredient contained $3.85 \mathrm{kcal}$ calorie, including 19 mg cholesterol from lard and yellow dye.

\subsection{Induction of Obesity}

A total of sixty mice were fed with high-fat diet as provided by purified commercial feeds containing all essential nutrients, vitamins, minerals and $60 \mathrm{kcal} \%$ of fat D12492 (Research Diets, New Brunswick, New Jersey, USA) for 16 weeks [92]. Its caloric composition was $20 \mathrm{kcal} \%$ protein, 20 $\mathrm{kcal} \%$ carbohydrate and $60 \mathrm{kcal} \%$ fat. Each gram of its ingredient contained $5.24 \mathrm{kcal}$, including 232 $\mathrm{mg}$ cholesterol from lard and blue dye. It was kept frozen and could last for six months. An amount of $60 \mathrm{kcal} \%$ fat is seldom practical in the case of the human diet. On the other hand, to induce obesity in mice more quickly and facilitating the research, $60 \mathrm{kcal} \%$ fat is frequently utilized, but when screening the impacts of a drug in genetic manipulation, the requirement may be $45 \mathrm{kcal} \%$ fat diet because a high $60 \% \mathrm{kcal} \%$ diet could inhibit a reversal of the effects [93].

The mice of the normal test group were fed with a normal purified diet (NC) consisting of $10 \%$ beef tallow (Research Diets, New Brunswick, New Jersey, United States of America) for 16 weeks, while the mice of the control group were fed a high-fat diet (HFD) for 16 weeks to elicit diet-induced obesity, when the body weight of these mice increased significantly were chosen for this study.

\subsection{Study Design for the Treatment Groups}

Sixty ICR male mice $(39.01 \pm 1.03 \mathrm{~g})$ body weight were randomly assigned into six groups, (10 mice/group). As shown in (Table 4 ) five groups were fed with a high-fat diet (HFD) and one group was fed standard chow (NC). The five HFD groups were divided into: HFD only (HFDC), HFD with orlistat $15.9 \mathrm{mg} / \mathrm{kg}$ body weight and dissolved in ethanol $20 \mathrm{mg} / \mathrm{mL}$ (HFD+orlistat) [92]. HFD with methanolic leaf extract of Clinacanthus nutans (MECN) at $500 \mathrm{mg} / \mathrm{kg}$ (HFD+CN500), HFD wiith MECN at $1000 \mathrm{mg} / \mathrm{kg}$ (HFD+CN1000) and HFD with MECN $1500 \mathrm{mg} / \mathrm{kg}$ (HFD+CN1500). Distilled water was used as a vehicle for dissolving and dispensing MECN by oral gavage, given once daily 
for 21-day. For the controls in HFDC and NC groups, the mice were given the distilled water without MECN.

Table 4 Clinacanthus nutans experimental design.

\begin{tabular}{lll}
\hline Group name & Treatment & \\
\hline HFDC & HFD mice control+drinking water & Non treated control \\
NC & Normal mice control+drinking water & Healthy control \\
HFD + Orlistat & HFD + Orlistat $(15.9 \mathrm{mg} / \mathrm{kg}$ per body weight $)$ & Positive control \\
HFD + CN500 & HFD $+C N(500 \mathrm{mg} / \mathrm{kg}$ per body weight $)$ & Low dose \\
HFD + CN1000 & HFD $+C N(1000 \mathrm{mg} / \mathrm{kg}$ per body weight $)$ & Intermediate dose \\
HFD $+\mathrm{CN} 1500$ & HFD $+\mathrm{CN}(1500 \mathrm{mg} / \mathrm{kg}$ per body weight $)$ & High dose \\
\hline
\end{tabular}

\subsection{Measurement of the Body Weight}

For the duration of the experiment, body weight was recorded after each week with a standard weighting balance to monitor the body weight changes. The food was given at $4 \mathrm{~g} /$ daily per mice and mice had access to water at all times. The body weight was recorded the study and changes expressed as \% at the end of the study. The rate of changes in body weight upon supplementation of C. nutans was determined using the equation.

\subsection{Determination of Muscle Cholesterol Levels}

Cholesterol level in muscle was determined by O-phthalaldehyde spectrophotometer with the maximum wavelength of $550 \mathrm{~nm}$ [94]. The cholesterol level was measured as described by Rudel and Morris [94]. One gram of muscle sample was crushed into small pieces. Three $\mathrm{mL}$ of $95 \%$ ethanol and two $\mathrm{ml}$ of $50 \%$ potassium hydroxide were mixed into each tube and vortexed for 20 seconds. The tubes were then heated in a water bath at $60^{\circ} \mathrm{C}$ for 10 minutes and later cooled at room temperature $\left(20^{\circ} \mathrm{C}\right)$. Then, $5 \mathrm{~mL}$ of hexane was carefully added to the tubes and mixed vigorously by vortexing for 20 seconds. Following this, one $\mathrm{mL}$ of distilled water was added, and mixing was done by vortexing. The tubes were then settled at room temperature for 15 minutes or until the separation between the aqueous and organic phase was completed. An amount of $0.5 \mathrm{~mL}$ of the hexane layer was later transferred into a clean tube and heated in a water bath at $90^{\circ} \mathrm{C}$, and eventually, hexane was evaporated to dryness at $60^{\circ} \mathrm{C}$ under nitrogen gas flow. The residue formed was suspended in $4 \mathrm{~mL}$ of ophthalaldehyde reagent $(0.5 \mathrm{mg}$ ophthalaldehyde in $1 \mathrm{~mL}$ of glacial acetic acid). The tubes were then kept at room temperature for 10 minutes. Then, $2 \mathrm{ml}$ of concentrated sulfuric acid was slowly pipetted down the inside of each tube. The samples were mixed thoroughly as described previously. The samples were then left standing for an additional 10 minutes, and the absorbance was read at $550 \mathrm{~nm}$ against the blank reagent. The reading at absorbance 550 nm was compared with a standard curve to determine the concentration of cholesterol. The same procedure was used for the standard curve according to the method of Rudel and Morris [94], except that the following amounts of cholesterol (Sigma L-4646) were assayed in place of the samples at $0,0.5,1,1.5$, and $2 \mu \mathrm{g}$, respectively. The concentration of cholesterol and standard were tested at $550 \mathrm{~nm}$ absorbance using a spectrophotometer (Secomam, Dumont, France). 


\subsection{Determination Malondialdehyde in Muscles}

Lipid peroxidation in muscle was established through malondialdehyde (MDA) assay. malondialdehyde is a secondary product of lipid peroxidation and is the primary substrate in the thiobarbituric acid reactive substances (TBARS) [95]. The release of MDA can be observed spectrophotometrically (Secomam, Dumont, France) by its ability to form a complex with thiobarbituric acid (TBA) and obtain an MDA-TBA adduct. This complex is a pink-colored complex with the absorbance of $532 \mathrm{~nm}$ [96]. Thiobarbituric acid reactive substances (TBARS) as indicators of lipid peroxidation were measured as described by Mercier et al. [96]. Muscle from mice weighing $500 \mathrm{mg}$ in every sample was homogenized in $4 \mathrm{~mL}$ of $1.15 \mathrm{M}$ of potassium chloride. Then, butylated hydroxytoluene (BHT) was prepared at a concentration of $0.1 \mathrm{mM}$ with Ultraturrax (1min, $6000 \mathrm{rpm}$ ) by dissolving $1.54 \mathrm{~g}$ of BHT in $50 \mathrm{~mL}$ ethanol and then following this; distilled water was added up to $100 \mathrm{~mL}$. Next, thiobarbituric acid (TBA) was prepared at a concentration of $0.8 \%$ by preparing $20 \%$ of the acetic acid solution and adding $0.8 \mathrm{~g}$ of TBA into the acetic acid solution. Meanwhile, $\mathrm{pH}$ was adjusted to 3.5 by adding sodium hydroxide during this time, ensuring TBA to be completely dissolved in acetic acid. After that, sodium dodecyl sulfate (SDS) at a concentration of $8.1 \%$ was prepared by dissolving $8.1 \mathrm{~g}$ of SDS in $100 \mathrm{~mL}$ of distilled water.

\subsubsection{Malondialdehyde Assay}

Sample containing about $100 \mu \mathrm{L}$ each was added with $200 \mu \mathrm{L}$ of distilled water. Next, $35 \mu \mathrm{L}$ of BHT was added to the sample. Finally, $165 \mu \mathrm{L}$ of SDS and $2 \mathrm{~mL}$ of TBA were added to the mixture. The sample was heated in a water bath for 60 minutes at $95^{\circ} \mathrm{C}$. The samples were then cooled to room temperature under running water. Next, $3 \mathrm{~mL}$ of n-butanol was added to the mixture and mixed for 60 seconds. Following this, the samples were centrifuged at $5000 \mathrm{rpm}$ for 10 minutes. The butanol layer was later separated from the aqueous phase by using a pipette. The absorbance of the butanol layer was read at absorbance $532 \mathrm{~nm}$ against pure butanol as a blank. Calculation of MDA was in $\mathrm{mg}$ MDA/ $\mathrm{kg}$ tissue and based on a standard curve generated from the standard 1,1,3,3-tetraethoxypropane at different concentrations [97].

\subsection{Analysis of Fatty Acid Composition in Muscles}

The total fatty acids were extracted from muscle tissues; the main solvents used were chloroform to methanol in 2:1 ratio. The solvents used were polar and had a high solubility for the lipid compound to remove lipid components from their binding sites of the cell membrane, lipoprotein, and glycolipids. The fatty acid composition of mice muscle was analyzed utilizing gas chromatography (GC). Prior to and following the extraction of fatty acid, all equipment including methylation tubes, screw caps, and extraction tube stoppers were subjected to a two-hour soaking in Decon 90 (Decon Laboratories Ltd., Sussex UK), scrubbed and then rinsed with tap water. Thereafter, they were again soaked, this time in distilled water overnight and rinsed once more, then oven-dried at $60^{\circ} \mathrm{C}$. Other glassware including the separating flasks, funnels, extraction tubes and round-bottomed flasks were washed in an automated laboratory glassware washer (Smeg Ltd., Oxon UK) with acid and alkaline washes for approximately three hours. Care was taken to ensure that all chemicals, solvents and laboratory supplies utilized for total lipid extraction and preparation of fatty acid methyl esters 
(FAME) were of the required analytical grade. All chemicals and solvents were free from contamination with rubber or fat derivatives. The screw caps of methylation tubes and vials were of Teflon. Chloroform and chloroform-methanol solvents, (Merck KGaA, Darmstadt, Germany) had 10 $\mathrm{mg} / \mathrm{L}$ of butylated hydroxytoluene (2, 6-di-tert-butyl-p-cresol) (Sigma Chemical Co., St. Louis, Missouri, USA) to inhibit the oxidative damage to fatty acids during extraction, methylation and storage.

\subsubsection{Total Lipid Extraction}

The extraction of total fatty acids was from muscle tissues employing chloroform to methanol (2:1) $(\mathrm{v} / \mathrm{v})$ based on the method of Folch et al. [98] and modified by Ebrahimi et al. [99]. The samples of muscle tissues $(0.5 \mathrm{mg}$ ) were ground by Grinder (IKA Analysentechnik GmBH, Germ any) and then homogenised in $40 \mathrm{~mL}$ chloroform to methanol (2:1) (v/v) utilizing an Ultra-Turrax T5 FU homogeniser (IKA Analysentechnik GmBH, Germany) in a $50 \mathrm{~mL}$ stoppered ground-glass extraction tube. Flushing with nitrogen into the tube was done prior to stoppering and vigorous shaking for five minutes. The tube was then left to stand for $12 \mathrm{~h}$ with intermittent shaking. Following this, about $5 \mathrm{~mL}$ was taken from the sample and transferred to plastic tubes. Five $\mathrm{mL}$ of chloroform to methanol mixture in 2:1 concentration was then added to the extracts. Chloroform/methanol was used to prevent oxidation of the samples during sample preparation. The mixture was then vortexed at $5000 \mathrm{rpm}$ for 20 seconds. Following this, $4 \mathrm{~mL}$ of distilled water was added to the mixture. The mixture was then vortexed again at $5000 \mathrm{rpm}$ for 40 seconds. To allow separation, the mixture was then centrifuged at $3000 \mathrm{rpm}$ for 5 minutes. The chloroform phase was separated from the aqueous phase by using a pipette and transferred to a methylated tube. An amount of $100 \mu \mathrm{L}$ of an internal standard consisting of heneicosanoic acid (C21:0) (Sigma Chemical, St. Louis, MO, USA) was introduced into every sample prior to transmethylation to establish the individual fatty acid level in the sample. Following this, the sample was heated in a water bath at $70^{\circ} \mathrm{C}$, and the solvent of the sample was dried using nitrogen gas. Two $\mathrm{mL}$ of potassium hydroxide $(\mathrm{KOH})(\mathrm{R} \& \mathrm{M}$ Chemicals, Essex, U.K.) was then added to the sample, followed by heating in a water bath at $95^{\circ} \mathrm{C}$ for 10 minutes. Next, $2 \mathrm{~mL}$ of $14 \%$ methanolic boron trifluoride (BF3) (Sigma Chemical Co., St. Louis, Missouri, USA) was introduced into the sample and heated in a water bath at $95^{\circ} \mathrm{C}$ for 20 minutes. After cooling, $4 \mathrm{~mL}$ of distilled water was added, and $4 \mathrm{~mL}$ of petroleum ether (boiling point $40-60^{\circ} \mathrm{C}$ ) and the mixture was vortexed for 60 seconds. Lastly, the petroleum ether with the FAME was placed into a $4 \mathrm{~mL}$ screw-capped vial (Kimble Glass Inc., USA), followed by flushing with nitrogen. The vial was then closed tightly and kept at $4^{\circ} \mathrm{C}$ until analysis by gas-liquid chromatography.

\subsubsection{Gas-Liquid Chromatography}

The methyl esters were quantified by GC (Agilent 7890A) employing a 30m x $0.25 \mathrm{~mm}$ ID $(0.20 \mu \mathrm{m}$ film thickness) Supelco SP-2330 capillary column (Supelco, Inc., Bellefonte, PA, USA). One microliter was injected with an autosampler into the chromatograph, equipped with a split/splitless injector and an FID detector. High purity nitrogen (Malaysian Oxygen Bhd., Malaysia) was the carrier gas at $40 \mathrm{~mL} / \mathrm{min}$. High purity hydrogen (Dominick Hunter, Parker Hannifin Ltd, UK) and compressed air (Malaysian Oxygen Bhd., Malaysia) were utilized for the flame ionization detector in the gas-liquid chromatograph. The injector temperature was programmed at $250^{\circ} \mathrm{C}$, and the detector temperature was $300^{\circ} \mathrm{C}$. The column temperature program initiated was run at $100^{\circ} \mathrm{C}$, for $2 \mathrm{~min}$, warmed to 
$170^{\circ} \mathrm{C}$ at $10^{\circ} \mathrm{C} / \mathrm{min}$, kept constant for $2 \mathrm{~min}$, warmed to $220^{\circ} \mathrm{C}$ at $7.5^{\circ} \mathrm{C} / \mathrm{min}$, and then kept constant for $20 \mathrm{~min}$ to ensure optimized separation. To identify the fatty acids, the relative comparison was made of FAME peak retention times of samples and standards obtained from Sigma (St. Louis, MO, USA). Both gravimetric calculations and normalized percentage (\%) of total FA were employed to establish the variances in FA composition. Peak areas were established and computed with a personal computer integrator (Hewlett-Packard, Avondale, PA). Automatic expression of the peak areas in absolute and percentage amounts of detected fatty acid was obtained with a programmed PC using Microsoft Excel 2000 (Microsoft Corp., Redmond, USA). The quantum of fatty acids is known by their relative proportions (normalized percentages of total fatty acids) [100, 101]. The normalized percentages explain the interactive and comparable relationships among fatty acids with regard to lipid quality, whereas the gravimetric concentration can indicate the real amount of fatty acids in tissues, in relation to nutritional intake.

\subsection{Liver Gene Expression Profile}

The liver tissue was used to examine the gene HSL, PPAR $\alpha$, PPAR $\gamma$, SREBP2, and SCD by using quantitative real-time polymerase chain reaction (qRT-PCR) method. The gene expression studies were done on the liver collected from high-fat-diet-induced obesity in ICR mice treated with MECN following 3 weeks of treatment and kept in the $-80^{\circ} \mathrm{C}$ freezer.

\subsubsection{Tissue Collection for RNA Extraction and Purification}

Following the sacrificing of the mice, the liver tissues were removed, snap-frozen in liquid nitrogen and stored at $-80^{\circ} \mathrm{C}$ until RNA extraction. Total RNA was extracted from $20 \mathrm{mg}$ of frozen liver tissue utilizing the RNase lipid tissue mini kit (Cat. number 74804, Qiagen, Hilden, Germany) and DNase digestion was completed during RNA purification with the RNase-Free DNase set (Qiagen, Hilden, Germany). About $20 \mathrm{mg}$ of the snap frozen liver samples from each animal in $1 \mathrm{~mL}$ of QIAzol lysis reagent was homogenized using a tissue homogenizer employing (IKA Analysentechnik GmBH, Germany).

\subsubsection{RNA Extraction from the Liver}

After homogenization of the liver tissue, $200 \mu \mathrm{L}$ of chloroform was added followed by centrifuging at 10,000 rpm for 15 minutes at $4^{\circ} \mathrm{C}$. The upper aqueous phase was then transferred to a different Eppendorf tube. This was followed by the addition of $600 \mu \mathrm{L}$ of $70 \%$ ethanol and mixed thoroughly by vortexing. Seven hundred $\mu \mathrm{L}$ of the sample was transferred to an RNeasy Mini spin column placed in a $2 \mathrm{~mL}$ collection tube. The lid was closed gently and centrifuging done for 15 seconds at $10,000 \mathrm{rpm}$ at room temperature $\left(15^{\circ} \mathrm{C}\right.$ to $\left.25^{\circ} \mathrm{C}\right)$. The flow-through was then removed. The same step was repeated with the remainder of the sample, after which 700 $\mu \mathrm{L}$ buffer RW1 was added to the RNeasy spin column, followed by centrifuging for 15 seconds at 10,000 rpm to wash the membrane. The flow-through was then removed, and $500 \mu \mathrm{L}$ of buffer RPE was added to the RNeasy spin column to wash the membrane. The flow-through was again removed, and the RNeasy spin column was transferred into a new $2 \mathrm{~mL}$ collection tube. The next step was the direct addition of $30 \mu \mathrm{L}$ of RNase-free water to the spin column membrane. To elute the RNA, centrifuging of the sample was done for 1 minute at 10,000 rpm according to the manufacturer's instructions and protocol. The DNase digestion was attained when RNA was purified with the RNAase-Free DNase set (Qiagen, Hilden, Germany) following the manufacturer's instrument. NanoDrop ND-1000 UV-Vis Spectrophotometer (NanoDrop Technologies, Wilmington, DE, 
USA) was used to determine the RNA purity by $260 / 280 \mathrm{~nm}$ ratio of absorbance reading. Following the purification of the total RNA $(1 \mu \mathrm{g})$ was reversely transcribed employing the Quantitect ${ }^{\circledR}$ reverse transcription kit (Qiagen, Hilden, Germany) following the procedure recommended by the manufacturer.

\subsubsection{Reverse Transcription of RNA to cDNA}

RNA samples were reverse transcribed to complementary DNAs (cDNA) to synthesize cDNA (Maxime RT-PCR PreMix Kit, USA) following the manufacturer's recommendation. The $4 \mu \mathrm{L}$ total RNA was mixed with premix containing Oligo (dT) 15 Primer and Random Primer-treated RNAase free water to btain a final volume of $20 \mu \mathrm{L}$ RNA. This was followed by the reverse-transcribed of RNA from each sample.

\subsubsection{Quantitative Real-Time Polymerase Chain Reaction (qRT- PCR)}

Real-time PCR was conducted using Bio-Rad CFX96 Touch (Bio-Rad Laboratories, Hercules, CA, USA) and also Quanti Nova SYBR Green PCR kit (Cat. No. 204054, Qiagen, Hilden, Germany). Specific primers used in the current work are listed in the (Table 5). All the primers utilized for RT-PCR were commercially obtained from Sigma USA. The optimization and validation of the real-time PCR assays of genes were based on a study by Ebrahimi et al. [102]. A standard curve of six-fold dilution series of cDNA was prepared in a 96-well plate. Quantitative reverse transcription PCR (qPCR) reactions were carried out using a master mix $25 \mu \mathrm{L}$ comprising of $9.5 \mu \mathrm{L}$ of RNase-free water, $12.5 \mu \mathrm{L}$ of Quanti- SYBR green (Qiagen, Hilden, Germany) $1 \mu \mathrm{L}$ cDNA, and $1 \mu \mathrm{L}$ of each respective forward and reverse primer were added in $1.5 \mathrm{~mL}$ tube and were mixed thoroughly and gently sterile $1.5 \mathrm{~mL}$ micro-centrifuge tubes were labelled from number 1 to 6 . A total of $24 \mu \mathrm{L}$ of the master mix was pipetted into each tube than by adding $1 \mu \mathrm{L}$ of diluted cDNAs into micro-centrifuge tubes. The mixtures were mixed thoroughly by vortexing gently and lastly, the microcentrifuge tubes were mixed and centrifuged briefly. Each replicate of the mixture was pipetted into a $0.2 \mathrm{~mL}$ low profile polypropylene tube covered with an ultra-clear cap (Biorad Laboratories, Inc., Hercules, CA using $20 \mu \mathrm{L}$ per well). The lowest concentration of cDNA was pipetted first, ending with the highest concentration. The microcentrifuge tubes were vortexed and centrifuges for 10 second, the mixtures were run on Bio-Rad CFX96 Touch (Bio-Rad Laboratories, Hercules, CA, USA) system machine. The thermos cycling program was used to amplify the target genes: $95^{\circ} \mathrm{C}$ (denaturation) for 10 seconds, $40 \mathrm{PCR}$ cycles at $95^{\circ} \mathrm{C}$ for 30 seconds, $60^{\circ} \mathrm{C}$ (annealing) for 20 seconds and $72^{\circ} \mathrm{C}$ (extension) for 20 seconds (Table 5 ). Fluorescence was computed at 15-second intervals to develop the melting curve. The efficiency of amplification was established for every primer pair by employing the serial dilutions of cDNA. The cycle numbers at which amplified DNA samples exceed the computer-generated fluorescence threshold level was normalized and comparison made to establish the relative gene expression. Assay negative controls consisted of no template cDNA controls and absence of reverse transcriptase controls. Immediately following the qPCR experiment, a melting curve analysis was analyzed to confirm the purity of amplicons and absence of primer dimers. Toward this end, the plate temperature was raised from $65^{\circ} \mathrm{C}$ to $95^{\circ} \mathrm{C}$ in $1{ }^{\circ} \mathrm{C}$ increments. The cycle numbers at which amplified DNA samples were higher than the computer-generated fluorescence threshold level were normalized and compared to establish the relative gene expression. Elevated cycle number values showed reduced initial levels of cDNA, and hence decreased levels of mRNA expression. 
Table 5 Sequences of primers used in qRT-PCR analysis

\begin{tabular}{|c|c|c|c|c|}
\hline $\begin{array}{l}\text { Target } \\
\text { gene }\end{array}$ & Sequences $5^{\prime}-3^{\prime}$ & $\begin{array}{l}\text { Length } \\
\text { (bp) }\end{array}$ & Temperature & Reference \\
\hline$\beta$ actin & $\begin{array}{l}\text { F CGCCATGGATGA TGA TAT TGC3 } \\
\mathrm{R} \text { AAG CGG CCT TGC ACA T3 }\end{array}$ & 123 & 55 & [102] \\
\hline PPAR $\alpha$ & $\begin{array}{ll}\text { F } & \text { TGC CAA GAT CTG AAA AAG CA } \\
R & \text { CCT CTT GGC CAG AGA CTT GA }\end{array}$ & 101 & 60 & [102] \\
\hline PPAR $\gamma$ & $\begin{array}{l}\text { F GCG GAG ATC TCC AGT GAT ATC } \\
\text { R TCA GCG ACT GGG ACT TTT CT }\end{array}$ & 121 & 60 & [102] \\
\hline HSL & $\begin{array}{l}\text { F GCT CCC ATC GTC AAG AATC } \\
\text { R TAA AGCGAA TGC GGT CC }\end{array}$ & 262 & 50 & [103] \\
\hline SREBP2 & $\begin{array}{ll}\text { F } & \text { ACA GCC GCC CTT CAA GTG } \\
R & \text { TCA CAG GCA TTG TGG TCA GAA }\end{array}$ & 460 & 62 & [102] \\
\hline$S C D$ & $\begin{array}{l}\text { F CCC AGC TGT CAG AGA AAA GG } \\
R \text { GAT GAA GCA CAA CAG CAG GA }\end{array}$ & 115 & 55 & [104] \\
\hline
\end{tabular}

F: forward, R: reverse, bp: base pair, PPAR $\alpha$ : Peroxisome proliferator-activated receptor- $\alpha$, PPAR $\gamma$ : Peroxisome proliferator-activated receptor- $\gamma$, HSL: hormone-sensitive lipase, SREBP2: Sterol regulatory element-binding protein, SCD: Stearoyl-Coenzyme A-Desaturase, $\beta$ actin: housekeeping gene.

\subsubsection{Primers Efficiency and Melting Curve}

Primers efficiency in real-time PCR was determined based on standard curve generated from six-fold serial dilution of cDNA. Slope value of around -3.3 and correlation coefficients of almost 1.0 will be acceptable. Single and new peak was expected which indicated that specific DNA fragment was amplified with no primer dimer formation or mispriming. The single peak would also indicate the purity of the amplified PCR product and that is free from contamination. Melting temperature was allowed to fluctuate within \pm 0.5 .

\subsection{7 qRT-PCR Calculation}

Individual samples were run in triplicate and averaged triplicates were used to assign cycle threshold (CT) values. In the current study the calibrator gene or housekeeping gene is $\beta$-actin and the test or targeted genes are HSL, PPAR $\alpha$, PPAR $\gamma$, SREBP and SCD. The $\triangle \mathrm{CT}$ values were generated by subtracting experimental CT values from the CT values for $\beta$-actin targets co-amplified with each sample. The group with the highest mean $\Delta C T$ value (lowest gene expression) per amplified gene target was set to zero and the mean $\Delta \mathrm{CT}$ values of the other groups were set relative to this calibrator $(\Delta \Delta \mathrm{CT})$. The $\Delta \Delta \mathrm{CT}$ values were calculated as powers of $2\left(-2^{\Delta \Delta \mathrm{CT}}\right)$ to account for the exponential doubling of the PCR [99]. Results were expressed and compared against the standard which was $\beta$ actin gene expressed in the positive control group which consist of untreated high-fat diet-induced mice. If the results showed a magnitude of $>1$, it was considered as up-regulated. If $<1$, the results would be considered as down-regulated.

\subsubsection{Statistical Analysis}

Data on body weight, organ weight, hematology, serum biochemical and histology parameters were analyzed using the one-way multivariate analysis of variance (ANOVA) procedure of the SAS software package, version 9.1 (SAS Institute Inc., Cary, NC). Substantially varying mean values were explained employing Duncan's test. Differences were accepted as statistically significant when 
p-value $<0.05$. Prior to analysis, all the data was checked for conformance to normality using the PROC UNIVARIATE procedure of the SAS software. All the results in the tables are shown as means \pm standard error of the means (SEM).

\section{Conclusions}

Based on the results discussed, it can be concluded that the high-fat diet treated methanolic leaf extract 1000 and $1500 \mathrm{mg} / \mathrm{kg}$ lead to significant reduction in body weight and visceral fat. The supplementation of crude MECN did not affect muscle MDA and muscle cholesterol in mice. This observation could be due to the duration of the trial. The dose of MECN at 500, 1000 and $1500 \mathrm{mg} / \mathrm{kg}$ clearly exhibited a significant reduction in saturated fatty acid and a heightened level of monounsaturated fatty acid. The qPCR analysis, a gene profiling of mRNA expression in the liver, showed that MECN treatment at $1500 \mathrm{mg} / \mathrm{kg}$ inhibits the HSL, PPAR $\gamma$, PPAR $\alpha$ and SCD1 mRNA gene actions. Thus, SCD mRNA genes are target candidates for drugs or dieting to manage obesity and insulin resistance. Activation or inhibition target genes involved in lipid metabolism homeostasis may alleviate obesity. Therefore, the methanolic leaf extract of Clinacanthus nutans has significant effects on the mRNA expression levels of different genes. The results suggested that MECN may be a useful therapeutic candidate for obesity.

\section{Supplementary Materials}

The Supplementary Materials are available online.

\section{Author Contributions}

Samiaa J. Abdulwahid designed and analysed data and wrote the paper; Dr. Young Meng Goh, Mahdi Ebrahimi and Zailina Binti Hashim supervised experiments, analysed data and edited the paper.

\section{Conflicts of Interest:}

The authors declare no conflict of interest.

\section{References}

1- Popkin, B. M.; Adair, L. S.; Ng, S. W. Global nutrition transition and the pandemic of obesity in developing countries. Nutr Rev 2012, 70(1), 3-21.

2- Ng, M.; Fleming, T.; Robinson, M.; Thomson, B.; Graetz, N.; Margono, C.; Abraham, J. P. Global, regional, and national prevalence of overweight and obesity in children and adults during 19802013: a systematic analysis for the Global Burden of Disease Study 2013. The lancet 2014, 384(9945), 766-781. 
3- Asia Roundtable on Food Innovation for Improved Nutrition (AROFIIN). Obesity in Asian, a call to action. Published on 10 Jul 2017 Available online: http://www.arofiin.org/News/tid/57/Obesity-in-ASEAN-A-Call-to-Action.

4- Wang, Y.; Beydoun, M. A.; Liang, L.; Caballero, B.; Kumanyika, S. K. Will all Americans become overweight or obese? Estimating the progression and cost of the US obesity epidemic. Obes 2008, 16(10), 2323-2330.

5- Amano, S. U. Local Macrophage Proliferation in Adipose Tissue is A Characteristic of Obesity-Associated Inflammation. PhD dissertation, Universiti of Massachusetts Medical School, 2013.

6- Kn, B. P.; Gopalan, V.; Lee, S. S.; Velan, S. S. Quantification of abdominal fat depots in rats and mice during obesity and weight loss interventions. Plos One 2014, 9(10), e108979.

7- Foster, M. T.; Pagliassotti, M. J. Metabolic alterations following visceral fat removal and expansion: Beyond anatomic location. Adipocyte 2012, 1(4), 192-199.

8- Targher, G.; Arcaro, G. Non-alcoholic fatty liver disease and increased risk of cardiovascular disease. Atherosclerosis 2007, 191(2), 235-240.

9- Gastaldelli, A.; Kozakova, M.; Højlund, K.; Flyvbjerg, A.; Favuzzi, A.; Mitrakou, A.; Balkau, B. Fatty liver is associated with insulin resistance, risk of coronary heart disease, and early atherosclerosis in a large European population. Hepatol. 2009, 49(5), 1537-1544.

10- Dinkova-Kostova, A. T.; Talalay, P. Direct and indirect antioxidant properties of inducers of cytoprotective proteins. Mol Nutr Food Res .2008, 52(S1).

11- Ranjbar, S.; Nayebi, N.; Moradi, L.; Mehri, A.; Larijani, B. and Abdollahi, M. The efficacy and safety of herbal medicines used in the treatment of hyperlipidemia; a systematic review. Curr Pharm Des 2010, 16(26), 2935-2947.

12- Mohamed, G. A.; Ibrahim, S. R.; Elkhayat, E. S.; El Dine, R. S. (2014). Natural anti-obesity agents. Bull. Faculty of Pharm. Cairo Univer 2014, 52(2), 269-284.

13- Ferraz, R. R. N.; Tiselius, H. G.; Heiberg, I. P. (2004). Fat malabsorption induced by gastrointestinal lipase inhibitor leads to an increase in urinary oxalate excretion. Kidney Int 2004, 66(2): 676-682.

14- Rudelle, S.; Ferruzzi, M. G.; Cristiani, I.; Moulin, J.; Mace, K.; Acheson, K. J.; Tappy, L. Effect of a Thermogenic Beverage on 24 Hour Energy Metabolism in Humans. Obes 2007, 15(2), 349-355.

15- Roosita, K.; Kusharto, C. M.; Sekiyama, M.; Fachrurozi, Y.; Ohtsuka, R. Medicinal plants used by the villagers of a Sundanese community in West Java, Indonesia. J Ethnopharmacol 2008, 115(1), 72-81.

16- Tu, S. F.; Liu, R. H.; Cheng, Y. B.; Hsu, Y. M. ; Du, Y. C. ; El-Shazly, M.; Chang, F. R. Chemical constituents and bioactivities of Clinacanthus nutans aerial parts. Molecules 2014, 19(12), 20382-20390.

17- Sarega, N.; Imam, M. U.; Ooi, D. J.; Chan, K. W.; Md Esa, N.; Zawawi, N.; Ismail, M. Phenolic rich extract from Clinacanthus nutans Attenuates Hyperlipidemia-Associated Oxidative Stress in Rats. Oxid Med Cell Longev. 2016. http://dx.doi.org/10.1155/2016/4137908.

18- Alam, A.; Ferdosh, S.; Ghafoor, K.; Hakim, A.; Juraimi, A. S.; Khatib, A.; Sarker, Z. I. Clinacanthus nutans: A review of the medicinal uses, pharmacology and phytochemistry. Asian Pac J Trop Med 2016, 9 (4), 402-409. 
19- Panmei, C.; Singh, P.; Gautam, S.; Variyar, P.; Shantibala Devi, G.; Sharma, A. Phenolic acids in Albizia bark used as a starter for rice fermentation in Zou preparation. J Food Agaric Environ 2007, 5(3), 147-150.

20- Nakazato, K.; Song, H.; Waga, T. Effects of dietary apple polyphenol on adipose tissues weights in Wistar rats. Exp Anim 2006, 55(4), 383-389.

21- Atanassova, M.; Georgieva, S.; Ivancheva, K. Total phenolic and total flavonoid contents, antioxidant capacity and biological contaminants in medicinal herbs. J Chem Technol Metall 2011, $46(1), 81-88$.

22- Chavalittumrong, P.; Attawish, A.; Rugsamon, P.; Chuntapet, P.Toxicological study of Clinacanthus nutans (Burm. f.) Lindau Warasan Krom Witthayasat Kan Phaet 1995. http://thaiagris.lib.ku.ac.th/eng/.

23- Lau, K. W.; Lee, S. K.; Chin, J. H. Effect of the methanol leaves extract of Clinacanthus nutans on the activity of acetylcholinesterase in male mice. J Acute Dis.2014, 3(1), 22-25.

24- Zakaria, Z. A.; Rahim, M. H. A.; Mohtarrudin, N.; Kadir, A. A.; Cheema, M. S.; Ahmad, Z.; Tohid, S. F. M. Acute and sub-chronic oral toxicity studies of methanol extract of Clinacanthus nutans in mice. Afr J Tradit Complement Altern Med 2016, 13(2), 210-222.

25- Ali, F.; Ismail, A.; Kersten, S. Molecular mechanisms underlying the potential anti-obesityrelated diseases effect of cocoa polyphenols. Mol Nutr Food Res 2014, 58(1), 33-48.

26- Mayoral, R.; Osborn, O.; McNelis, J.; Johnson, A. M.; Izquierdo, C. L.; Chung, H.; Ofrecio, J. M. (2015). Adipocyte SIRT1 knockout promotes PPAR $\gamma$ activity, adipogenesis and insulin sensitivity in chronic-HFD and obesity. Mol Metab 2015, 4(5), 378-391.

27- Karahashi, M.; Ishii, F.; Yamazaki, T.; Imai, K.; Mitsumoto, A.; Kawashima, Y.; Kudo, N. Up-regulation of stearoyl-CoA desaturase 1 increases liver MUFA content in obese Zucker but not Goto-Kakizaki rats. Lipids 2013, 48(5), 457-467.

28- Finkelstein, E. A.; Khavjou, O. A.; Thompson, H.; Trogdon, J. G.; Pan, L.; Sherry, B.; Dietz, W. Obesity and severe obesity forecasts through 2030. Am J Prev Med 2012, 42(6), 563-570.

29- Jang, W. S.; Choung, S.Y. Antiobesity effects of the ethanol extract of laminaria japonica areshoung in high-fat-diet-induced obese rat. Evid Based Complementary Altern Med 2013, 492807, 1-17.

30- Nishikawa, S.; Yasoshima, A.; Doi, K.; Nakayama, H.; Uetsuka, K. Involvement of sex, strain and age factors in high-fat diet-induced obesity in C57BL/6J and BALB/cA mice. Exp Anim 2007, 56(4), 263-272.

31- Kadir, N.A.; Rahmat, A.; Jaafat, H.Z. Protective effects of tamarillo (Cyphomandra betacea) extract against high-fat diet-induced obesity in Sprague-Dawley rats. J Obes 2015. http://dx.doi.org/10.1155/2015/846041.

32- Teodoro, J. S.; Zouhar, P.; Flachs, P.; Bardova, K.; Janovska, P.; Gomes, A. P.; Kopecký, J. Enhancement of brown fat thermogenesis using chenodeoxycholic acid in mice. Int $J$ Obes 2014, 38(8), 1027-1034.

33- Zhou, Y.; Rui, L. (2013). Leptin signaling and leptin resistance. Front Med 2013, 7(2), 207-222.

34- Mashmoul, M.; Azlan, A.; Yusof, B. N. M.; Khaza'ai, H.; Mohtarrudin, N.; Boroushaki, M. T. Effects of saffron extract and crocin on anthropometrical, nutritional and lipid profile parameters of rats fed a high-fat diet. J Funct Food 2014, 8, 180-187. 
35- Kumar, S.; Alagawadi, K. R.; Rao, M. R. (2011). Effect of Argyreia speciosa root extract on cafeteria diet-induced obesity in rats. Indian J Pharmacol 2011, 43(2), 163-167.

36- Hayashi, T.; Boyko, E. J.; McNeely, M. J.; Leonetti, D. L.; Kahn, S. E.; Fujimoto, W. Y. Visceral adiposity, not abdominal subcutaneous fat area, is associated with an increase in future insulin resistance in Japanese Americans. Diabetes 2008, 57(5), 1269-1275.

37- Bailey, S. A.; Zidell, R. H.; Perry, R. W. Relationships between organ weight and body/brain weight in the rat: what is the best analytical endpoint? Toxicol Pathol 2004, 32(4), 448-466.

38- Sakdarat, S.; Shuyprom, A.; Pientong, C.; Ekalaksananan, T.; Thongchai, S. Bioactive constituents from the leaves of Clinacanthus nutans Lindau. Bioorg Med Chem 2009, 17(5), 1857-1860.

39- Montelius, C.; Erlandsson, D.; Vitija, E.; Stenblom, E.; Egecioglu, E.; Erlanson-Albertsson, C. Body weight loss, reduced urge for palatable food and increased release of GLP-1 through daily supplementation with green-plant membranes for three months in overweight women. Appetite 2014, 81, 295-304.

40- Cho, A. S.; Jeon, S. M.; Kim, M. J.; Yeo, J.; Seo, K. I.; Choi, M. S.; Lee, M. K. (2010). Chlorogenic acid exhibits anti-obesity property and improves lipid metabolism in high-fat diet-induced-obese mice. Food Chem Toxicol 2010, 48(3), 937-943.

41- Wu, T. ; Qi, X. ; Liu, Y. ; Guo, J. ; Zhu, R. ; Chen, W. ; Yu, T. (2013). Dietary supplementation with purified mulberry (Morus australis Poir) anthocyanins suppresses body weight gain in high-fat diet fed C57BL/6 mice. Food Chem. 2013, 141(1), 482-487.

42- Baba, S.; Natsume, M.; Yasuda, A.; Nakamura, Y.; Tamura, T.; Osakabe, N.; Kondo, K. Plasma LDL and HDL cholesterol and oxidized LDL concentrations are altered in normo-and hypercholesterolemic humans after intake of different levels of cocoa powder. J Nutr 2007, 137(6), 1436-1441.

43- Al-Moosawi, S. Effect of Polyphenols on Gluhaecoregulatory Biomarkers Blood Pressure and Lipid Profile in Overweight and Obese Subjects. PhD dissertations, Universiti Queen Margaret, 2010.

44- Ondrejovicova, I.; Muchova, J.; Mislanova, C.; Nagyova, Z.; Durackova, Z. Hypercholesterolemia, oxidative stress and gender dependence in children. Prague Med Rep 2010, 111(4), 300-312.

45- Droge, W. Free radicals in the physiological control of cell function. Physiol Rev 2002, 82(1), 47-95.

46- Sen, A.; Mishra, S.; Ghosh, A.; Bhattacharjee, B.; De, S. D.; Ghosh, A. K.; Bandyopadhyay, D. Aqueous leaf extract of Tulsi (Ocimum sanctum) protects against high-fat diet-induced injury to rat liver through antioxidant mechanisms: a dose-and time-dependent study. J Pharm Res 2017, 11(4), 334-351.

47- Keaney, J. F.; Larson, M. G.; Vasan, R. S.; Wilson, P. W. F.; Lipinska, I.; MCorey, D.; Benjamin, E. J. Obesity and systemic oxidative stress clinical correlates of oxidative stress in the Framingham study. Arterioscler, Thromb Vasc Biol 2003, 23(3), 434-439.

48- Olusi, S. O. Obesity is an independent risk factor for plasma lipid peroxidation and depletion of erythrocyte cytoprotectic enzymes in humans. Int J Obes 2002, 26(9), 1159-1164.

49- Russell, A. P.; Gastaldi, G.; Bobbioni-Harsch, E.; Arboit, P.; Gobelet, C.; Dériaz, O.; Giacobino, J. P. (2003). Lipid peroxidation in skeletal muscle of obese as compared to endurance-trained humans: a case of good vs. bad lipids? FEBS Lett 2003, 551(1-3), 104-106. 
50- Kono, Y.; Kobayashi, K.; Tagawa, S.; Adachi, K.; Ueda, A.; Sawa, Y.; Shibata, H. Antioxidant activity of polyphenolics in diets: rate constants of reactions of chlorogenic acid and caffeic acid with reactive species of oxygen and nitrogen. Biochim Biophys Acta 1997, 1335(3), 335-342.

51- Fernandez-Mar, M. I.; Mateos, R.; Garcia-Parrilla, M. C.; Puertas, B.; Cantos-Villar, E. Bioactive compounds in wine: Resveratrol, hydroxytyrosol and melatonin: A review. Food Chem 2012, 130(4), 797-813.

52- Macedo, L. F. L.; Rogero, M. M.; Guimaraes, J. P.; Granato, D.; Lobato, L. P.; Castro, I. A. Effect of red wines with different in vitro antioxidant activity on oxidative stress of high-fat diet rats. Food Chem 2013, 137(1), 122-129.

53- Lecumberri, E.; Goya, L.; Mateos, R.; Alia, M.; Ramos, S.; Izquierdo-Pulido, M.; Bravo, L. (2007). A diet rich in dietary fiber from cocoa improves lipid profile and reduces malondialdehyde in hypercholesterolemic rats. Nutr 2007, 23(4), 332-341.

54- Magnusson, Y. K.; Friberg, P.; Sjavall, P.; Malm, J.; Chen, Y. TOF-SIMS analysis of lipid accumulation in the skeletal muscle of ob/ob mice. Obes 2008, 16(12), 2745-2753.

55- Morselli, E.; Mariño, G.; Bennetzen, M.V.; Eisenberg, T.; Megalou, E; Schroeder, S. Spermidine and resveratol induce autophagy by distinct pathways converging on the acetylproteome. J Cell Biol 2011, 192(4), 615-629.

56- Graf, D.; Seifert, S.; Jaudszus, A.; Bub, A.; Watzl, B. Anthocyanin-rich juice lowers serum cholesterol, leptin, and resistin and improves plasma fatty acid composition in -fischer rats. Plos One 2013, 8(6), e66690.

57- Andersson, A.; Nalsen, C.; Tengblad, S.; Vessby, B. Fatty acid composition of skeletal muscle reflects dietary fat composition in humans. Am J Clin Nutr 2002, 76(6), 1222-1229.

58- De Caterina, R. N-3 fatty acids in cardiovascular disease. N Engl J Med 2011, 364(25), 2439-2450.

59- Mustapa, A. N.; Martin, A.; Mato, R. B.; Cocero, M. J. Extraction of phytocompounds from the medicinal plant Clinacanthus nutans Lindau by microwave-assisted extraction and supercritical carbon dioxide extraction. Ind Crops Prod 2015, 74, 83-94.

60- Calder, P. C.; Ahluwalia, N.; Brouns, F.; Buetler, T.; Clement, K.; Cunningham, K.; Lansink, M. Dietary factors and low-grade inflammation in relation to overweight and obesity. Br J Nutr 2011, 106(S3), S1-S78.

61- Mezei, O.; Li, Y.; Mullen, E.; Ross-Viola, J. S.; Shay, N. F. Dietary isoflavone supplementation modulates lipid metabolism via PPARalpha-dependent and -independent mechanisms. Physiol Genomics 2006, 26(1), 8-14.

62- Feige, J. N.; Gelman, L.; Michalik, L.; Desvergne, B.; Wahli, W. From molecular action to physiological outputs: peroxisome proliferator-activated receptors are nuclear receptors at the crossroads of key cellular functions. Prog in Lipid Res 2006, 45(2), 120-159.

63- Reddy, J. K. Peroxisome proliferators and peroxisome proliferator-activated receptor $\alpha$ : biotic and xenobiotic sensing. Am J Pathol 2004, 164(6), 2305-2321.

64- Kersten, S. Mechanisms of nutritional and hormonal regulation of lipogenesis. EMBO Report 2001, 2(4), 282-286.

65- Siersbæk, R.; Nielsen, R.; Mandrup, S. PPAR $\gamma$ in adipocyte differentiation and metabolismNovel insights from genome-wide studies. FEBS Lett 2010, 584(15), 3242-3249. 
66- Zhang, Y.; Xie, M.; Xue, J.; Gu, Z. Osthole improves fat milk-induced fatty liver in rats: modulation of hepatic PPAR-alpha/gamma-mediated lipogenic gene expression. Planta Med 2007, 73(08): 718-724.

67- Yin, X. M.; Ding, W. X.; Gao, W. (2008). Autophagy in the liver. Hepatol 2008, 47(5): 1773-1785.

68- Jia, Y.; Kim, S.; Kim, J.; Kim, B.; Wu, C.; Lee, J. H.; Lee, S. J. Ursolic acid improves lipid and glucose metabolism in high-fat-fed C57BL/6J mice by activating peroxisome proliferatoractivated receptor alpha and hepatic autophagy. Mol Nutr Food Res 2015, 59(2), 344-354.

69- Kim, S. Y.; Kim, A. Y.; Lee, H. W.; Son, Y. H.; Lee, G. Y.; Lee, J. W.; Kim, J. B. miR-27a is a negative regulator of adipocyte differentiation via suppressing PPAR $\gamma$ expression. Biochem Biophys Res Commun 2010, 392(3), 323-328.

70- Harada, M.; Hanada, S.; Toivola, D. M.; Ghori, N.; Omary, M. B. Autophagy activation by rapamycin eliminates mouse Mallory-Denk bodies and blocks their proteasome inhibitormediated formation. Hepatol 2008, 47(6), 2026-2035.

71- Elkhoury, D.; Anderson, G. H. Recent advances in dietary proteins and lipid metabolism. Curr Opin Lipidol 2013, 24(3), 207-213.

72- Gervois, P.; Fruchart, J. C.; Staels, B. Drug Insight: mechanisms of action and therapeutic applications for agonists of peroxisome proliferator-activated receptors. Nat Clin Pract Endocrinol Metab 2007, 3(2), 145-156.

73- Ferre, P. The biology of peroxisome proliferator-activated receptors. Diabetes 2004, 53(suppl 1): S43-S50. https://doi.org/10.2337/diabetes.53.2007.S43.

74- Hwang, C. S.; Loftus, T. M.; Mandrup, S.; Lane, M. D. Adipocyte differentiation and leptin expression. Annu Rev Cell Dev Biol 1997, 13(1), 231-259.

75- Tammen, S.; Friso, S.; Choi, S. Epigenetics: the link between nature and nurture. Mol Aspects Med 2013, 34(4), 753-764.

76- Banerjee, S.; Ghoshal, S.; Porter, T. D. Phosphorylation of hepatic AMP-activated protein kinase and liver kinase B1 is increased after a single oral dose of green tea extract to mice. Nutr Res 2012, 32 (12), 985-990.

77- Ardevol, A.; Blade, C.; Salvado, M. J.; Arola, L. Changes in lipolysis and hormone-sensitive lipase expression caused by procyanidins in 3T3-L1 adipocytes. Int J Obes 2000, 24(3), 319.

78- Pinent, M.; Blade, M. C.; Salvadó, M. J.; Arola, L.; Ardévol, A. Intracellular mediators of procyanidin-induced lipolysis in 3T3-L1 adipocytes. J Agric Food Chem 2005, 53(2), 262-266.

79- Jobgen, W.; Meininger, C. J.; Jobgen, S. C.; Li, P.; Lee, M. J.; Smith, S. B.; Wu, G. Dietary L-arginine supplementation reduces white fat gain and enhances skeletal muscle and brown fat masses in diet-induced obese rats. J Nutr 2008, 139(2), 230-237.

80- Popeijus, H. E.; Saris, W. H.; Mensink, R. P. Role of stearoyl-CoA desaturases in obesity and the metabolic syndrome. Int J Obes 2008, 32, 1076-1082.

81- An, S.; Han, J. I.; Kim, M.J.; Park, J.S.; Han, J.M.; Baek, N.I.; Jeong, T.S. Ethanolic extracts of Brassica campestris spp. rapa roots prevent high-fat diet-induced obesity via 3-adrenergic regulation of white adipocyte lipolytic activity. J Med Food 2010, 13(2), 406-414.

82- Cunha, C. A.; Lira, F. S.; Rosa Neto, J. C.; Pimentel, G. D.; Souza, G. I. H.; da Silva, C. M.G.; Oller do Nascimento, C. M. Green tea extract supplementation induces the lipolytic pathway, attenuates obesity, and reduces low-grade inflammation in mice fed a high-fat diet. Mediators Inflamm 2013. http://dx.doi.org/10.1155/2013/635470. 
83- Hu, C.C.; Qing, K.; Chen, Y. Diet-induced changes in stearoyl-CoA desaturase 1 expression in obesity-prone and -resistant mice. Obes Res 2004, 212, 1264-1270.

84- Asilmaz, E.; Cohen, P.; Miyazaki, M.; Dobrzyn, P., Ueki, K.; Fayzikhodjaeva, G. Site and mechanism of leptin action in a rodent form of congenital lipodystrophy. J Clin Invest 2004, 113(3), 414-424.

85- Klaus, S.; Pultz, S.; Thone-Reineke, C.; Wolfram, S. Epigallocatechin gallate attenuates diet-induced obesity in mice by decreasing energy absorption and increasing fat oxidation. Int $J$ Obes 2005, 29(6), 615-623.

86- Horie, T.; Ono, K.; Horiguchi, M.; Nishi, H.; Nakamura, T.; Nagao, K.; Hasegawa, K. MicroRNA-33 encoded by an intron of sterol regulatory element-binding protein 2 (Srebp2) regulates HDL in vivo. Proc Natl Acad Sci 2010, 107(40), 17321-17326.

87- Matsuzaka, T.; Shimano, H.; Yahagi, N.; Amemiya-Kudo, M.; Okazaki, H.; Tamura, Y.; Hasty, A. Insulin-independent induction of sterol regulatory element-binding protein-1c expression in the livers of streptozotocin-treated mice. Diabetes 2004, 53(3), 560-569.

88- Foufelle, F.; Ferré, P. New perspectives in the regulation of hepatic glycolytic and lipogenic genes by insulin and glucose: a role for the transcription factor sterol regulatory element binding protein-1c. Biochem J 2002, 366(2), 377-391.

89- Toyama, T.; Kudo, N.; Hibino, Y.; Mitsumoto, A.; Nishikawa, M.; Kawashima, Y. Effects of pioglitazone on stearoyl-CoA desaturase in obese Zucker fa/fa rats. J Pharmacol Sci 2007, 104(2), 137-145.

90- Vidal-Puig, A. J.; Considine, R. V.; Jimenez-Liñan, M.; Werman, A.; Pories, W. J.; Caro, J. F.; Flier, J. S. Peroxisome proliferator-activated receptor gene expression in human tissues. Effects of obesity, weight loss, and regulation by insulin and glucocorticoids. J Clin Invest 1997, 99(10), 2416-2422.

91- Abdulwahid, S. J.; Ebrahimi, M.; Goh, Y.; Adeyemi, K. D.; Ismail, H.; Hashim, Z. Methanolic extract of Clinacanthus nutans leaves can alter adipocyte cellularity, inflammation and acetyl cholinesterase activity in male obese mice. J Obes Weight Loss Ther 2017, 7(2).

92- Sung, Y.Y.; Yoon, T.; Yang, W. K.; Kim, S. J.; Kim, D. S.; Kim, H. K. The anti-obesity effect of Polygonum aviculare L. ethanol extract in high-fat diet-induced obese mice. Evid Based Complement Alternat Med 2013. http://dx.doi.org/10.1155/2013/626397.

93- Wang, C. Y.; Liao, J. K. A mouse model of diet-induced obesity and insulin resistance. In: Weichhaer T. (eds) mTOR Methods in Molecular Biology (Methods and Protocols), vol 821; Humana Press: New York, NY, USA, 2012, (pp. 421-433).

94- Rudel, L. L.; Morris, M. D. Determination of cholesterol using O-phthalaldehyde. J Lipid Res 1973, 14(3), 364-366.

95- Pryor, W. A. Can vitamin E protect humans against the pathological effects of ozone in smog? Am J Clin Nutr 1991, 53(3), 702-722. https://doi.org/10.1093/ajcn/53.3.702.

96- Mercier, Y.; Gatellier, P.; Viau, M.; Remignon, H.; Renerre, M. Effect of dietary fat and vitamin E on colour stability and on lipid and protein oxidation in turkey meat during storage. Meat Sci 1998, 48(3-4), 301-318.

97- Lynch, S. M.; Frei, B. Mechanisms of copper-and iron-dependent oxidative modification of human low density lipoprotein. J Lipid Res 1993, 34(10), 1745-1753.

98- Folch, J.; Lees, M.; Sloane Stanley, G. A simple method for the isolation and purification of total lipids from animal tissues. J Biol Chem 1957, 226(1), 497-509. 
99- Ebrahimi, M.; Rajion, M. A.; Goh, Y. M.; Sazili, A. Q.; Schonewille, J. T. Effect of linseed oil dietary supplementation on fatty acid composition and gene expression in adipose tissue of growing goats. BioMed Res Int 2013. http://dx.doi.org/10.1155/2013/194625.

100- Huerta-Leidenz N. O., Cross H. R., Savell J. W., Lunt D. K., Baker J. F., and Smith S. B. (1996). Fatty acid composition of subcutaneous adipose tissue from male calves at different stages of growth. Journal of Animal Sciences, 74(6), 1256-1264.

101- Alfaia, C. M.; Ribeiro, V. S.; Lourenc, M. R.; Auaresma, M. A.; Martins, S. I.; Portugal, A. P.; Fontes, C. M.; Bessa, R. J.; Castro, M. L.; Prater, J. A. Fatty acid composition, conjugated linoleic acid isomers and cholesterol in beef from crossbred bullocks intensively produced and from Alentejana purebred bullocks reared according to Carnalentejana- PDO specifications. Meat Sci 2006, 72, 425-436.

102- Ebrahimi, M.; Rajion, M. A.; Meng, G. Y.; Soleimani, A. Omega-3 fatty acid enriched chevon (goat meat) lowers plasma cholesterol levels and alters gene expressions in rats. BioMed Res Int 2014. http://dx.doi.org/10.1155/2014/749341.

103-Jang, W.S.; Choung, S.Y. Antiobesity effects of the ethanol extract of laminaria japonica areshoung in high-fat-diet-induced obese rat. Evid-Based Complementary Alternat Med 2013, 492807, 1-17.

104- Tao, R.; Xiong, X.; DePinho, R. A.; Deng, C. X.; Dong, X. C. Hepatic SREBP-2 and cholesterol biosynthesis are regulated by FoxO3 and Sirt6. J Lipid Res 2013, 54(10), 2745-2753. 